\title{
Spatio-Temporal Variation and Monsoon Effect on the Temperature Lapse Rate of a Subtropical Island
}

\author{
Ching-An Chiu ${ }^{1}$, Po-Hsiung Lin ${ }^{2, *}$, and Chih-Yung Tsai ${ }^{3}$ \\ ${ }^{1}$ Department of Forestry / Experimental Forest, National Chung Hsing University, Taichung, Taiwan, ROC \\ ${ }^{2}$ Department of Atmospheric Sciences, National Taiwan University, Taipei, Taiwan, ROC \\ ${ }^{3}$ Department of Education, University of Taipei, Taipei, Taiwan, ROC
}

Received 31 August 2012, accepted 8 November 2013

\begin{abstract}
Temperature lapse rate (TLR) has been widely used in the prediction of mountain climate and vegetation and in many ecological models. The aims of this paper are to explore the spatio-temporal variations and monsoon effects on the TLR in the subtropical island of Taiwan with its steep Central Mountain Region (CMR). A TLR analysis using the 32-year monthly mean air temperatures and elevations from 219 weather stations (sea level to $3852 \mathrm{~m}$ a.s.1.) was performed based on different geographical regions and monsoon exposures. The results revealed that the average TLR for all of Taiwan is $-5.17^{\circ} \mathrm{C} \mathrm{km}^{-1}$, with a general tendency to be steeper in summer and shallower in winter. The results are also shallower than the typical or global average TLR of $-6.5^{\circ} \mathrm{C} \mathrm{km}^{-1}$. During the prevailing northeast monsoon season (winter), the TLR exhibits a contrast between the windward side (steeper, $-5.97^{\circ} \mathrm{C} \mathrm{km}^{-1}$ ) and the leeward side (shallower, $-4.51^{\circ} \mathrm{C} \mathrm{km}^{-1}$ ). From the diagnosis on spatial characteristics of monthly cloud amount and vertical atmospheric profiles, this contrasting phenomenon may be explained by the warming effect of onshore stratus clouds (500 - $2500 \mathrm{~m}$ depth) on cold and dry Siberian monsoon air on the windward side of the CMR. On the southwestern leeward side of the CMR, the low-level $(1500 \mathrm{~m})$, the weak ventilation atmosphere and temperature inversion make the TLR shallower than on the windward side.
\end{abstract}

Key words: Temperature lapse rate, Prevailing monsoon, Spatio-temporal variation, Taiwan

Citation: Chiu, C. A., P. H. Lin, and C. Y. Tsai, 2014: Spatio-temporal variation and monsoon effect on the temperature lapse rate of a subtropical island. Terr. Atmos. Ocean. Sci., 25, 203-217, doi: 10.3319/TAO.2013.11.08.01(A)

\section{INTRODUCTION}

Air temperature is an important variable in biogeographical and ecological models (Prentice et al. 1992; Guisan and Zimmermann 2000; Elith and Leathwick 2009). However, continuous and complete temperature records are often unavailable, especially in mountainous areas, where meteorological stations are usually sparse (Chiu et al. 2009; Burt and Holden 2010). Because air temperature gradually decreases with elevation in the troposphere, the change rate, called the temperature lapse rate (TLR), can facilitate the spatial interpolation of temperature at a given place and time to generate a climate grid (e.g., Bolstad et al. 1998; Stahl et al. 2006; Cannon et al. 2012). Thus, the TLR was widely used to predict mountain climate and vegetation $(\mathrm{Su}$ 1984a; Tang 2006; Bertoldi et al. 2010). The TLR, used as

\footnotetext{
* Corresponding author

E-mail:polin@ntu.edu.tw
}

the most important predictor of temperature variability, can also contribute to predicting the response of mountain plants to climate change (Lenoir et al. 2008; Trivedi et al. 2008).

A commonly used value of the environmental TLR is $-6.5^{\circ} \mathrm{C} \mathrm{km}^{-1}$ (Barry and Chorely 2009) or $-6.0^{\circ} \mathrm{C} \mathrm{km}^{-1}$ (Willmott and Matsuura 2001). However, the use of this constant TLR everywhere and throughout the year may be problematic (Komatsu et al. 2010) because the TLR varies with atmospheric processes, seasonal cycles, geographical and topographical positions, air saturation, and other factors (Su 1984a; Pepin 2001; Doran et al. 2002). Some numerical models use a specified TLR that remains constant in space and time (e.g., the MT-CLIM model, Running et al. 1987), but this approach will likely lead to large errors (Huang et al. 2008). Many papers have offered no rationale for their use of the traditional constant value of $-6.5^{\circ} \mathrm{C} \mathrm{km}^{-1}$ (e.g., Stutter et al. 2006; Asaoka and Kominami 2012; Samanta et al. 
2012). However, this traditional TLR value is merely a spatially global and temporally climatic average (Blandford et al. 2008). It has been confirmed that both spatial and temporal variations of the TLR exist in various regions and for different seasons. For example, Rolland (2003) demonstrated spatial and seasonal variations of the TLR over southwestern Europe. Tang and Fang (2006) revealed that the TLR showed large spatial and seasonal changes in Mt. Taibai, China. Daly et al. (2008) accounted for the major physiographic factors influencing the linear temperature-elevation relationship to improve the interpolation of temperature grids. Minder et al. (2010) found geographic (windward side versus leeward side) and monthly variations of the TLR in the Cascade Mountains, USA. Consequently, changes of the TLR in particular regions and for different seasons should be estimated to improve the accuracy of temperature predictions.

Taiwan is a subtropical mountainous island influenced by the seasonal changes of the Asian monsoon climate. The temperature is highly related to elevation, but the TLR varies considerably in different regions of Taiwan. Su (1984a) reported that the TLR of January and July varied from place to place between -3.08 and $-6.98^{\circ} \mathrm{C} \mathrm{km}^{-1}$. Guan et al. (2009) modeled the TLR by linear or second-order functions for the island's mountain region. For April - December, the TLR was linear, between -4.93 and $-5.62^{\circ} \mathrm{C} \mathrm{km}^{-1}$, with steeper TLR in the late spring and summer and shallower TLR in the fall and early winter. For January - March, the TLR was a second-order function, between -3.22 and $-3.61^{\circ} \mathrm{C} \mathrm{km}^{-1}$, but it was steeper by -0.42 to $-0.50^{\circ} \mathrm{C} \mathrm{km}^{-1}$ for each kilometer of increase in elevation. Chiu et al. (2009) used linear regression to interpolate temperature using the elevations and coordinates of stations as predictors. The island-wide monthly TLR values were between -4.36 and $-5.68^{\circ} \mathrm{C} \mathrm{km}^{-1}$, and monthly temperatures were slightly modified by the geographical coordinates of the stations during January June and September - December. It is preferable to use regional observed data to derive the representative TLR as a substitute for the constant TLR. Meanwhile, the altitudinal distribution patterns of plants in Taiwan are noticeably affected by the northeast monsoon (Chiou et al. 2010). The spatial distribution of precipitation between the summer half-year and winter half-year affected by alternate monsoons is highly uneven (Chiu et al. 2009). Thus, it is necessary to further explore how the spatio-temporal variation and monsoon affect the TLR. The aims of this paper are to present the monthly patterns of the TLR in different regions and to explore the influence of the prevailing winter monsoon on the TLR in subtropical Taiwan. Section 2 gives the data sources and methodology, and the results and discussion will be presented in section 3 .

\section{MATERIALS AND METHODS}

\subsection{Study Area}

Taiwan is a mountainous island with an area of ca. $36000 \mathrm{~km}^{2}$, bisected by the Tropic of Cancer and located off the southeastern coast of China (Fig. 1a). The topography, illustrated in Fig. 1b, shows that the north-south trending Central Mountain Range (CMR) has more than 50 peaks above $3000 \mathrm{~m}$. The weather and climate of Taiwan are strongly affected by the circulation of the East Asia monsoon (Su 1984a; Araguás-Araguás et al. 1998; Lin et al. 2009; Peng et al. 2010). The two major prevailing monsoons are the northeast monsoon from the Asian continent (centered on Siberia) during the winter half-year (October - March) and the southwest monsoon from the equatorial maritime region during the summer half-year. Figures $1 \mathrm{c}$ and $\mathrm{d}$ show the climatic (1991 - 2010) January and July precipitation and low-level $(925 \mathrm{hPa})$ wind flow patterns provided by the European Centre for Medium-Range Weather Forecasts (ECMWF). These alternating winter and summer monsoons plus the sharp topography govern the natural vegetation and climate of Taiwan (Su 1984a, 1984b, 1985).

\subsection{Climatic Data}

Chiu et al. (2009) used a quality-control procedure to screen the 32-year (1961 - 2002) meteorological data, including metadata (e.g., coordinates, elevation) and daily observed data (temperature and precipitation), of all stations obtained from Taiwan's Central Weather Bureau (CWB). Through this quality-control procedure based on a geographic information system, $13.5 \%$ of stations were rejected due to missing or erroneous metadata, and $8.3 \%$ of the daily observed data were rejected because of extreme errors or unreasonable temporal sequences and spatial patterns. The climatic data extracted from the database used in this paper (219 stations and their monthly mean temperatures, Tm, ${ }^{\circ} \mathrm{C}$ ) are shown in Fig. 1b. The altitudinal zones and concentrations of the weather stations listed in Table 1 are highly irregular in space. The stations are particularly sparse in higher elevation areas. There are $178(81.3 \%)$ stations below $500 \mathrm{~m}$ a.s.l. and only $12(5.5 \%)$ above $1500 \mathrm{~m}$ a.s.l., and the average yearly temperature of all stations gradually decreases with increasing altitude.

\subsection{Geographical Climatic Regions}

By using the ten geographical climatic regions suggested by Su (1985) (red polygons in Fig. 1b) and the spatial and temporal patterns of precipitation (Chiu et al. 2009), Taiwan can be divided into four geographical climatic regions: the northwest region $(\mathrm{NWr})$, with 104 weather stations $(\mathrm{n}=104)$, the northeast region (NEr; $n=43$ ), the southwest region $(\mathrm{SWr} ; \mathrm{n}=60)$, and the southeast region $(\mathrm{SEr} ; \mathrm{n}=12)$. These stations within the four climatic regions can be regrouped into a north region $(\mathrm{Nr}=\mathrm{NWr}+\mathrm{NEr} ; \mathrm{n}=147)$, a south region $(\mathrm{Sr}=\mathrm{SWr}+\mathrm{SEr} ; \mathrm{n}=72)$, a west region $(\mathrm{Wr}=\mathrm{NWr}+\mathrm{SWr}$; 
$\mathrm{n}=164)$, and an east region $(\mathrm{Er}=\mathrm{NEr}+\mathrm{SEr} ; \mathrm{n}=55)$. Based on Su's (1985) suggestions, Taiwan can also be divided into windward (WWr; $\mathrm{n}=43)$ and leeward $(\mathrm{LWr} ; \mathrm{n}=129)$ regions of the prevailing northeast monsoon. Table 2 lists the number of weather stations in the various climatic regions. The spatio-temporal variation and monsoon effect on the TLR are analyzed further in this study.

\subsection{Data Analysis}

The temperature was assumed to decrease linearly with

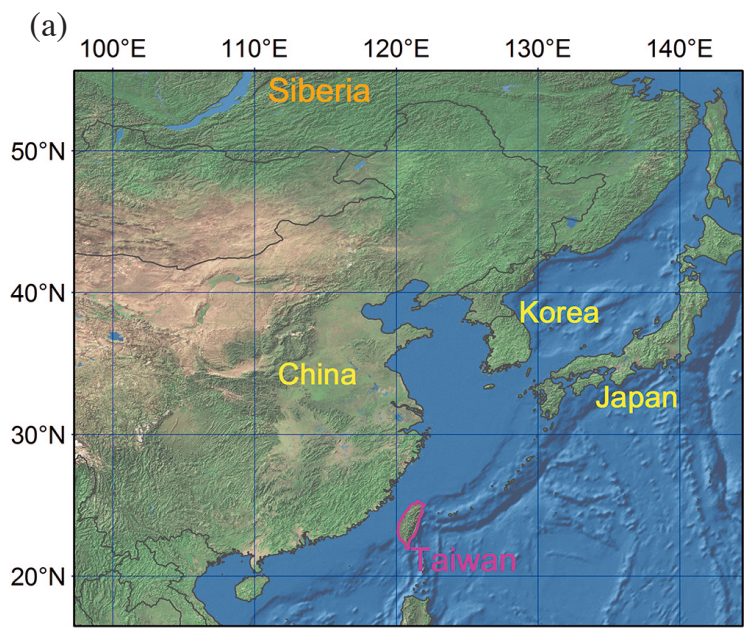

(c)

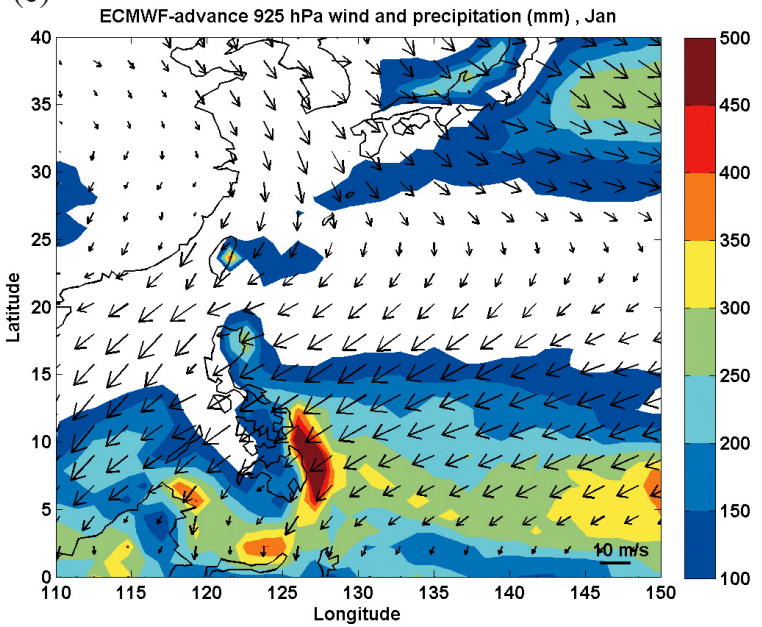

an increase in altitude. The linear regression model below was used to calculate the monthly TLR in different geographical climatic regions.

$T=\alpha+\beta E$

where:

$T$ : the dependent variable, or temperature $\left({ }^{\circ} \mathrm{C}\right)$ at the stations;

$\alpha$ : the intercept, or temperature at sea level $\left({ }^{\circ} \mathrm{C}\right)$;

$\beta$ : the slope coefficient, or the TLR $\left({ }^{\circ} \mathrm{C} \mathrm{km}{ }^{-1}\right)$;

$E$ : the independent variable, or the elevation above sea level $(\mathrm{km})$ at the stations.

(b)

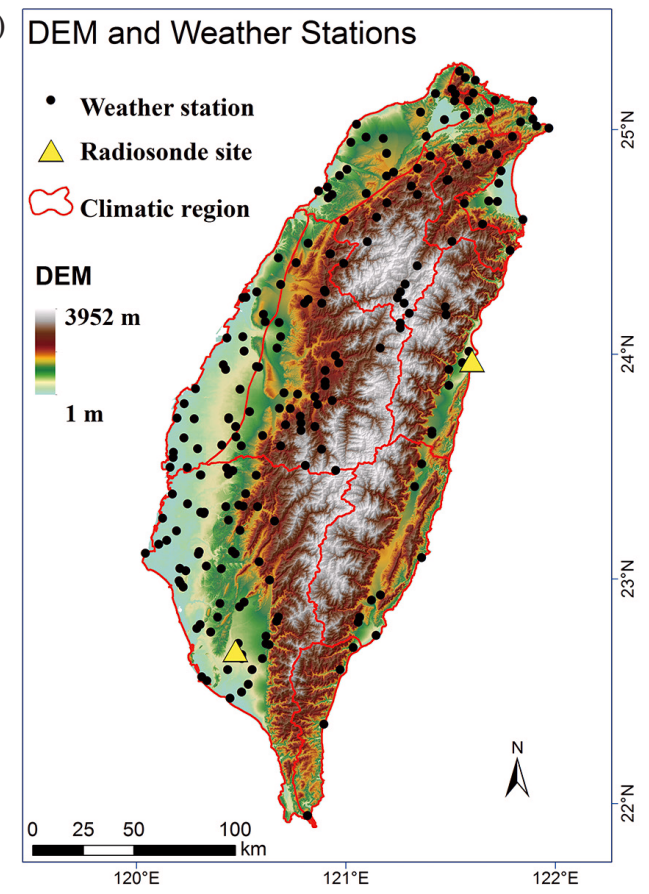

(d)

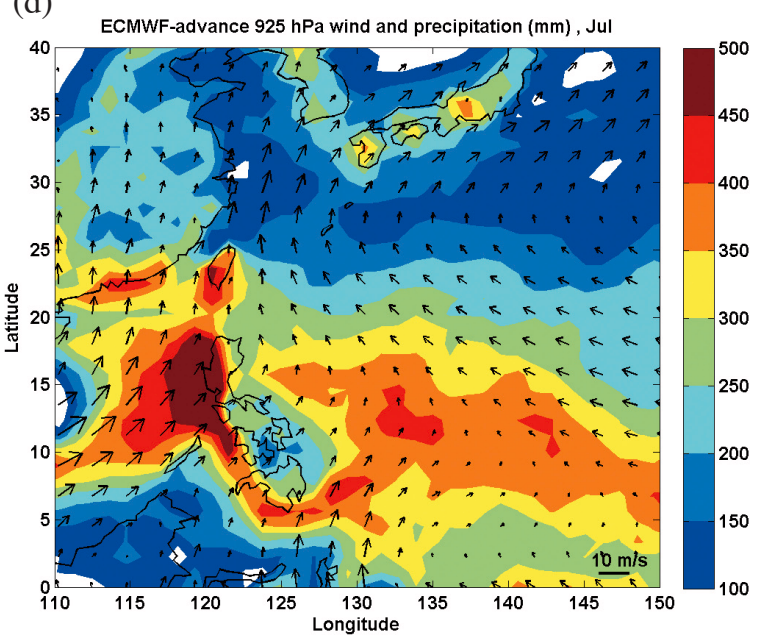

Fig. 1. (a) Location of the study area in East Asia; (b) digital elevation model (DEM) and locations of the weather stations used in this study. The red lines represent the borderlines of Su's (1985) geographical climatic regions. The yellow triangles from north to south represent the locations of Hualien (in northeast/windward region) and Pingtung (in southwest/leeward region) radiosonde sites. (c) 20-year (1991 - 2010) mean of monthly precipitation amount (unit: $\mathrm{mm}$ ) and $925 \mathrm{hPa}$ wind vector in January at northwestern Pacific region. The data is ECMWF advanced 1.125 degree resolution grid dataset. (d) Same as (c), but in July. 
Table 1. Number of weather stations and their average yearly temperature among different altitudinal zones.

\begin{tabular}{ccc}
\hline Altitudinal zones & $\begin{array}{c}\text { Number of } \\
\text { stations }\end{array}$ & $\begin{array}{c}\text { Average yearly } \\
\text { temperature }\left({ }^{\circ} \mathbf{C}\right)\end{array}$ \\
\hline $0-500 \mathrm{~m}$ & 177 & 22.72 \\
$500-1000 \mathrm{~m}$ & 19 & 19.05 \\
$1000-1500 \mathrm{~m}$ & 11 & 17.82 \\
$1500-2000 \mathrm{~m}$ & 4 & 14.02 \\
$2000-2500 \mathrm{~m}$ & 4 & 12.16 \\
$2500-3000 \mathrm{~m}$ & 1 & 9.47 \\
$3000-3500 \mathrm{~m}$ & 2 & 6.50 \\
$3500-4000 \mathrm{~m}$ & 1 & 3.93 \\
\hline
\end{tabular}

Table 2. Number of weather stations analyzed in variously geographical climatic regions.

\begin{tabular}{lc}
\hline Geographical climatic regions & Number of stations \\
\hline NWr (northwest region) & 104 \\
NEr (northeast region) & 43 \\
SWr (southwest region) & 60 \\
SEr (southeast region) & 12 \\
Nr (north region $=$ NWr + NEr) & 147 \\
Sr (south region $=$ SWr + SEr) & 72 \\
Er (east region = NEr + SEr) & 55 \\
Wr (west region = NWr + SWr) & 164 \\
WWr (windward region) & 43 \\
LWr (leeward region) & 129 \\
\hline
\end{tabular}

The slope, coefficient of determination $\left(\mathrm{R}^{2}\right)$, and $\mathrm{p}$-value was recorded for each linear regression. The calculation and illustration of changes of TLR and $\mathrm{R}^{2}$ were performed using the SPSS 18.0 (PASW, IBM SPSS Statistics, NY, USA) and SigmaPlot 12.0 (Systat Software Inc., San Jose, CA, USA) software.

TLR is normally negative because the temperature usually decreases with increasing elevation. The description of "increase" or "decrease" as well as "higher" or "lower" in the TLR may lead to confusion. In this study, we adopt a "steeper" TLR to describe a more negative one (greater decrease in temperature with elevation) and a "shallower" TLR to describe a less strongly negative or even positive one (temperature inversion) (Pepin 2001).

\section{RESULTS AND DISCUSSION}

For further details on the following results regarding spatio-temporal variation of TLR the reader may refer to our Supplementary Data (Table 3 - 13).

\subsection{General Pattern of the TLR in the Entire Island}

The monthly TLR was estimated from 219 stations in the entire island region (Ir). As an example, illustrated in Fig. 2a, the TLR in January was $-4.75^{\circ} \mathrm{C} \mathrm{km}^{-1}$ by linear regression $\left(R^{2}=0.82\right)$. The monthly TLR ranged between -4.63 and $-5.68^{\circ} \mathrm{C} \mathrm{km}^{-1}$ (Fig. 2b), with an annual mean of $-5.17^{\circ} \mathrm{C} \mathrm{km}^{-1}$. These results were similar to those of Chiu et al. (2009) and Guan et al. (2009) and resembled those in Nepal $\left(-5.3^{\circ} \mathrm{C} \mathrm{km}^{-1}\right.$, Bhattarai et al. 2004), Hawaii $\left(-5.5^{\circ} \mathrm{C} \mathrm{km}^{-1}\right.$, Loope and Giambelluca 1998), and Kinabalu $\left(-5.5^{\circ} \mathrm{C} \mathrm{km}^{-1}\right.$, Kitayama 1992). Our results are shallower than the typical or global average TLR of $-6.5^{\circ} \mathrm{C} \mathrm{km}^{-1}$ (Blandford et al. 2008; Barry and Chorely 2009). Comparing the dry adiabatic lapse rate (ca. $-9.8^{\circ} \mathrm{C} \mathrm{km}^{-1}$ ) and moist (saturated) adiabatic lapse rate (ca. $-4.0^{\circ} \mathrm{C} \mathrm{km}^{-1}$ ), the average TLR of Taiwan is closer to the latter. In general, the TLR tends to be steeper in an oceanic climate and shallower in a continental climate (Jobbágy and Jackson 2000). Thus, in contrast with the global average TLR of $-6.5^{\circ} \mathrm{C} \mathrm{km}^{-1}$, the shallower TLR in Taiwan might be caused by its geographical location (Fig. 1a) and the surrounding oceanic climate or ocean current system (Leuschner 2000). The role of the CMR terrain effect and the monsoon flow in changing the TLR will be discussed more.

The seasonal change of the TLR in Ir, as shown in Fig. 2b, was steeper during the summer half-year (mean $-5.48^{\circ} \mathrm{C} \mathrm{km}^{-1}$, steepest $-5.68^{\circ} \mathrm{C} \mathrm{km}^{-1}$ ) and shallower during winter half-year (mean $-4.89^{\circ} \mathrm{C} \mathrm{km}^{-1}$, shallowest $-4.63^{\circ} \mathrm{C} \mathrm{km}^{-1}$ ). This seasonal pattern of the TLR was in agreement with most other studies (Tang and Fang 2006; Blandford et al. 2008; Huang et al. 2008; Minder et al. 2010; Kirchner et al. 2013). However, the absence of this seasonal pattern has been observed in some studies, perhaps due to an insufficient number of stations and periods too short to calculate temperature means (Rolland 2003). The coefficient of determination $\left(\mathrm{R}^{2}\right.$, Fig. 2b) was higher (mean 0.92) in the summer half-year than in the winter half-year (mean 0.82). This more robust relationship between temperature and elevation in the summer half-year also agrees with other studies, such as Rolland (2003) and Minder et al. (2010). We expect that the broken convective cumulus clouds on land in the CMR region during summer time might provide a thicker boundary layer and steeper TLR. On the other hand, stable stratus clouds formed in winter time trap colder air near sea level and restrict water vapor to lower altitudes. Thus, the TLR becomes shallower in the cold seasons. More evidence from monthly cloud-amount retrieval from geostationary satellite and vertical-profiling observation by balloon radiosonde will be presented later to support this explanation.

\subsection{Spatio-Temporal Variation of the TLR in Different Geographical Regions}

To take a sufficient number of weather stations into account, we merged Su's (1985) ten geographical climatic 
Table 3. The linear regression $(T=\alpha+\beta \times E)$ between monthly mean temperature $\left(T\right.$, in $\left.{ }^{\circ} \mathrm{C}\right)$ and elevation $(E$, in $\mathrm{km})$ in $\operatorname{Ir}(219$ stations). $\alpha$ is the intercept or temperature at sea level $\left({ }^{\circ} \mathrm{C}\right) ; \beta$ is the slope coefficient or TLR $\left({ }^{\circ} \mathrm{C} \mathrm{km}^{-1}\right) . T_{1}$ refers to January, $T_{2}$ to February, and so on.

\begin{tabular}{cccc}
\hline Regression formula $\boldsymbol{T}=\boldsymbol{\alpha}+\boldsymbol{\beta} \times \boldsymbol{E}$ & $\mathbf{R}^{2}$ & $\mathbf{F}$ & $\mathbf{p}$ \\
\hline$T_{1}=16.812+(-4.752 \times E)$ & 0.817 & 966.288 & 0.000 \\
$T_{2}=17.362+(-4.659 \times E)$ & 0.770 & 727.249 & 0.000 \\
$T_{3}=19.813+(-4.634 \times E)$ & 0.756 & 673.049 & 0.000 \\
$T_{4}=23.163+(-5.063 \times E)$ & 0.825 & 1022.935 & 0.000 \\
$T_{5}=25.755+(-5.431 \times E)$ & 0.885 & 1672.414 & 0.000 \\
$T_{6}=27.625+(-5.549 \times E)$ & 0.951 & 4170.249 & 0.000 \\
$T_{7}=28.622+(-5.675 \times E)$ & 0.958 & 4919.801 & 0.000 \\
$T_{8}=28.288+(-5.650 \times E)$ & 0.959 & 5084.191 & 0.000 \\
$T_{9}=27.001+(-5.534 \times E)$ & 0.940 & 3405.775 & 0.000 \\
$T_{10}=24.773+(-5.239 \times E)$ & 0.888 & 1726.778 & 0.000 \\
$T_{11}=21.703+(-5.009 \times E)$ & 0.861 & 1348.864 & 0.000 \\
$T_{12}=18.474+(-4.857 \times E)$ & 0.847 & 1204.101 & 0.000 \\
\hline
\end{tabular}

Table 5. The linear regression $(T=\alpha+\beta E)$ between monthly mean temperature $\left(T\right.$, in $\left.{ }^{\circ} \mathrm{C}\right)$ and elevation $(E$, in $\mathrm{km})$ in $\mathrm{NEr}$ (43 stations). $\alpha$ is the intercept or temperature at sea level $\left({ }^{\circ} \mathrm{C}\right) ; \beta$ is the slope coefficient or TLR $\left({ }^{\circ} \mathrm{C} \mathrm{km}^{-1}\right)$. $T_{1}$ refers to January, $T_{2}$ to February, and so on.

\begin{tabular}{rccc}
\hline Regression formula $\boldsymbol{T}=\boldsymbol{\alpha}+\boldsymbol{\beta} \times \boldsymbol{E}$ & $\mathbf{R}^{2}$ & $\mathbf{F}$ & $\mathbf{p}$ \\
\hline$T_{1}=16.157+(-5.914 \times E)$ & 0.843 & 220.322 & 0.000 \\
$T_{2}=16.377+(-5.725 \times E)$ & 0.861 & 253.857 & 0.000 \\
$T_{3}=18.543+(-5.061 \times E)$ & 0.785 & 149.601 & 0.000 \\
$T_{4}=21.443+(-5.022 \times E)$ & 0.895 & 351.190 & 0.000 \\
$T_{5}=24.095+(-5.251 \times E)$ & 0.930 & 546.651 & 0.000 \\
$T_{6}=26.809+(-5.372 \times E)$ & 0.906 & 397.379 & 0.000 \\
$T_{7}=28.380+(-5.926 \times E)$ & 0.922 & 486.028 & 0.000 \\
$T_{8}=28.050+(-6.025 \times E)$ & 0.925 & 503.021 & 0.000 \\
$T_{9}=26.098+(-6.003 \times E)$ & 0.945 & 700.807 & 0.000 \\
$T_{10}=23.564+(-5.914 \times E)$ & 0.899 & 365.130 & 0.000 \\
\hline$T_{11}=20.598+(-6.128 \times E)$ & 0.904 & 385.357 & 0.000 \\
\hline$T_{12}=17.779+(-6.260 \times E)$ & 0.886 & 319.735 & 0.000 \\
\hline
\end{tabular}

Table 4 . The linear regression $(T=\alpha+\beta \times E)$ between monthly mean temperature $\left(T\right.$, in $\left.{ }^{\circ} \mathrm{C}\right)$ and elevation $(E$, in $\mathrm{km})$ in $\mathrm{NWr}(104$ stations). $\alpha$ is the intercept or temperature at sea level $\left({ }^{\circ} \mathrm{C}\right) ; \beta$ is the slope coefficient or TLR $\left({ }^{\circ} \mathrm{C} \mathrm{km}{ }^{-1}\right) . T_{1}$ refers to January, $T_{2}$ to February, and so on.

\begin{tabular}{cccc}
\hline Regression formula $\boldsymbol{T}=\boldsymbol{\alpha}+\boldsymbol{\beta} \times \boldsymbol{E}$ & $\mathbf{R}^{2}$ & $\mathbf{F}$ & $\mathbf{p}$ \\
\hline$T_{1}=16.210+(-4.371 \times E)$ & 0.927 & 1297.851 & 0.000 \\
$T_{2}=16.635+(-4.184 \times E)$ & 0.899 & 904.565 & 0.000 \\
$T_{3}=19.085+(-4.167 \times E)$ & 0.886 & 795.599 & 0.000 \\
$T_{4}=22.772+(-4.740 \times E)$ & 0.934 & 1432.190 & 0.000 \\
$T_{5}=25.586+(-5.202 \times E)$ & 0.964 & 2722.094 & 0.000 \\
$T_{6}=27.586+(-5.450 \times E)$ & 0.978 & 4630.636 & 0.000 \\
$T_{7}=28.701+(-5.643 \times E)$ & 0.975 & 3995.337 & 0.000 \\
$T_{8}=28.433+(-5.653 \times E)$ & 0.976 & 4226.992 & 0.000 \\
$T_{9}=27.093+(-5.434 \times E)$ & 0.976 & 4095.803 & 0.000 \\
$T_{10}=24.624+(-4.988 \times E)$ & 0.954 & 2117.335 & 0.000 \\
$T_{11}=21.446+(-4.712 \times E)$ & 0.944 & 1715.506 & 0.000 \\
$T_{12}=18.051+(-4.526 \times E)$ & 0.939 & 1577.928 & 0.000 \\
\hline
\end{tabular}

Table 6 . The linear regression $(T=\alpha+\beta \times E)$ between monthly mean temperature $\left(T\right.$, in $\left.{ }^{\circ} \mathrm{C}\right)$ and elevation $(E$, in $\mathrm{km})$ in $\mathrm{SWr}(60$ stations). $\alpha$ is the intercept or temperature at sea level $\left({ }^{\circ} \mathrm{C}\right) ; \beta$ is the slope coefficient or TLR $\left({ }^{\circ} \mathrm{C} \mathrm{km}^{-1}\right) . T_{1}$ refers to January, $T_{2}$ to February, and so on.

\begin{tabular}{rrrr}
\hline Regression formula $\boldsymbol{T}=\boldsymbol{\alpha}+\boldsymbol{\beta} \times \boldsymbol{E}$ & $\mathbf{R}^{2}$ & $\mathbf{F}$ & $\mathbf{p}$ \\
\hline$T_{1}=17.554+(-2.860 \times E)$ & 0.281 & 22.694 & 0.000 \\
$T_{2}=18.520+(-3.041 \times E)$ & 0.298 & 24.594 & 0.000 \\
$T_{3}=21.197+(-3.603 \times E)$ & 0.384 & 36.104 & 0.000 \\
$T_{4}=24.562+(-4.757 \times E)$ & 0.664 & 114.395 & 0.000 \\
$T_{5}=26.959+(-6.028 \times E)$ & 0.816 & 256.590 & 0.000 \\
$T_{6}=28.158+(-6.312 \times E)$ & 0.848 & 324.285 & 0.000 \\
$T_{7}=28.674+(-6.510 \times E)$ & 0.832 & 288.102 & 0.000 \\
$T_{8}=28.281+(-6.113 \times E)$ & 0.800 & 232.560 & 0.000 \\
$T_{9}=27.541+(-6.363 \times E)$ & 0.817 & 259.305 & 0.000 \\
$T_{10}=25.754+(-5.763 \times E)$ & 0.787 & 213.881 & 0.000 \\
$T_{11}=22.628+(-4.537 \times E)$ & 0.652 & 108.497 & 0.000 \\
$T_{12}=19.166+(-3.411 \times E)$ & 0.403 & 39.190 & 0.000 \\
\hline
\end{tabular}


Table 7. The linear regression $(T=\alpha+\beta \times E)$ between monthly mean temperature $\left(T\right.$, in $\left.{ }^{\circ} \mathrm{C}\right)$ and elevation $(E$, in $\mathrm{km})$ in $\mathrm{SEr}(12$ stations), $\alpha$ is the intercept or temperature at sea level $\left({ }^{\circ} \mathrm{C}\right) ; \beta$ is the slope coefficient or TLR $\left({ }^{\circ} \mathrm{C} \mathrm{km}^{-1}\right) . T_{1}$ refers to January, $T_{2}$ to February, and so on.

\begin{tabular}{rccc}
\hline Regression formula $\boldsymbol{T}=\boldsymbol{\alpha}+\boldsymbol{\beta} \times \boldsymbol{E}$ & $\mathbf{R}^{2}$ & $\mathbf{F}$ & $\mathbf{p}$ \\
\hline$T_{1}=19.099+(-5.624 \times E)$ & 0.301 & 4.307 & 0.065 \\
$T_{2}=19.642+(-6.872 \times E)$ & 0.301 & 4.300 & 0.065 \\
$T_{3}=21.830+(-7.649 \times E)$ & 0.349 & 5.372 & 0.043 \\
$T_{4}=24.296+(-7.239 \times E)$ & 0.387 & 6.309 & 0.031 \\
$T_{5}=26.516+(-7.440 \times E)$ & 0.495 & 9.808 & 0.011 \\
$T_{6}=28.106+(-6.166 \times E)$ & 0.426 & 7.427 & 0.021 \\
$T_{7}=29.173+(-6.005 \times E)$ & 0.345 & 5.276 & 0.044 \\
$T_{8}=28.659+(-6.303 \times E)$ & 0.530 & 11.282 & 0.007 \\
$T_{9}=27.373+(-6.613 \times E)$ & 0.570 & 13.234 & 0.005 \\
$T_{10}=25.457+(-6.302 \times E)$ & 0.624 & 16.587 & 0.002 \\
$T_{11}=22.828+(-5.589 \times E)$ & 0.265 & 3.596 & 0.087 \\
$T_{12}=20.220+(-5.008 \times E)$ & 0.205 & 2.578 & 0.139 \\
\hline
\end{tabular}

Table 9. The linear regression $(T=\alpha+\beta \times E)$ between monthly mean temperature $\left(T\right.$, in $\left.{ }^{\circ} \mathrm{C}\right)$ and elevation $(E$, in $\mathrm{km})$ in $\mathrm{Sr}(72 \mathrm{sta}-$ tions). $\alpha$ is the intercept or temperature at sea level $\left({ }^{\circ} \mathrm{C}\right) ; \beta$ is the slope coefficient or TLR $\left({ }^{\circ} \mathrm{C} \mathrm{km}^{-1}\right)$.

\begin{tabular}{rccc}
\hline Regression formula $\boldsymbol{T}=\boldsymbol{\alpha}+\boldsymbol{\beta} \times \boldsymbol{E}$ & $\mathbf{R}^{2}$ & $\mathbf{F}$ & $\mathbf{p}$ \\
\hline$T_{1}=17.756+(-2.898 \times E)$ & 0.237 & 21.796 & 0.000 \\
$T_{2}=18.635+(-3.134 \times E)$ & 0.273 & 26.325 & 0.000 \\
$T_{3}=21.229+(-3.723 \times E)$ & 0.365 & 40.300 & 0.000 \\
$T_{4}=24.476+(-4.857 \times E)$ & 0.613 & 110.907 & 0.000 \\
$T_{5}=26.863+(-6.096 \times E)$ & 0.773 & 238.073 & 0.000 \\
$T_{6}=28.152+(-6.309 \times E)$ & 0.824 & 328.506 & 0.000 \\
$T_{7}=28.764+(-6.472 \times E)$ & 0.787 & 258.808 & 0.000 \\
$T_{8}=28.339+(-6.105 \times E)$ & 0.780 & 248.764 & 0.000 \\
$T_{9}=27.509+(-6.378 \times E)$ & 0.804 & 287.365 & 0.000 \\
$T_{10}=25.696+(-5.794 \times E)$ & 0.773 & 238.012 & 0.000 \\
$T_{11}=22.642+(-4.567 \times E)$ & 0.609 & 109.142 & 0.000 \\
$T_{12}=19.309+(-3.427 \times E)$ & 0.349 & 37.524 & 0.000 \\
\hline
\end{tabular}

Table 8 . The linear regression $(T=\alpha+\beta \times E)$ between monthly mean temperature $\left(T\right.$, in $\left.{ }^{\circ} \mathrm{C}\right)$ and elevation $(E$, in $\mathrm{km})$ in $\mathrm{Nr}(147$ stations). $\alpha$ is the intercept or temperature at sea level $\left({ }^{\circ} \mathrm{C}\right) ; \beta$ is the slope coefficient or TLR $\left({ }^{\circ} \mathrm{C} \mathrm{km}^{-1}\right) . T_{1}$ refers to January, $T_{2}$ to February, and so on.

\begin{tabular}{rrrr}
\hline Regression formula $\boldsymbol{T}=\boldsymbol{\alpha}+\boldsymbol{\beta} \times \boldsymbol{E}$ & $\mathbf{R}^{2}$ & $\mathbf{F}$ & $\mathbf{p}$ \\
\hline$T_{1}=16.098+(-4.437 \times E)$ & 0.903 & 1343.519 & 0.000 \\
$T_{2}=16.453+(-4.228 \times E)$ & 0.875 & 1012.250 & 0.000 \\
$T_{3}=18.845+(-4.150 \times E)$ & 0.857 & 871.526 & 0.000 \\
$T_{4}=22.300+(-4.610 \times E)$ & 0.895 & 1231.904 & 0.000 \\
$T_{5}=25.073+(-5.044 \times E)$ & 0.927 & 1829.027 & 0.000 \\
$T_{6}=27.325+(-5.362 \times E)$ & 0.965 & 3960.441 & 0.000 \\
$T_{7}=28.574+(-5.621 \times E)$ & 0.968 & 4447.351 & 0.000 \\
$T_{8}=28.280+(-5.629 \times E)$ & 0.969 & 4459.192 & 0.000 \\
$T_{9}=26.718+(-5.353 \times E)$ & 0.953 & 2942.510 & 0.000 \\
$T_{10}=24.205+(-4.917 \times E)$ & 0.917 & 1603.541 & 0.000 \\
$T_{11}=21.070+(-4.686 \times E)$ & 0.905 & 1378.574 & 0.000 \\
$T_{12}=17.853+(-4.577 \times E)$ & 0.911 & 1482.919 & 0.000 \\
\hline
\end{tabular}

Table 10. The linear regression $(T=\alpha+\beta \times E)$ between monthly mean temperature $\left(T\right.$, in $\left.{ }^{\circ} \mathrm{C}\right)$ and elevation $(E$, in $\mathrm{km})$ in $\operatorname{Er}(55$ stations). $\alpha$ is the intercept or temperature at sea level $\left({ }^{\circ} \mathrm{C}\right) ; \beta$ is the slope coefficient or TLR $\left({ }^{\circ} \mathrm{C} \mathrm{km}^{-1}\right)$.

\begin{tabular}{rrrr}
\hline Regression formula $\boldsymbol{T}=\boldsymbol{\alpha}+\boldsymbol{\beta} \times \boldsymbol{E}$ & $\mathbf{R}^{2}$ & $\mathbf{F}$ & $\mathbf{p}$ \\
\hline$T_{1}=16.988+(-6.644 \times E)$ & 0.673 & 109.193 & 0.000 \\
$T_{2}=17.253+(-6.515 \times E)$ & 0.656 & 101.221 & 0.000 \\
$T_{3}=19.379+(-5.837 \times E)$ & 0.604 & 80.849 & 0.000 \\
$T_{4}=22.170+(-5.696 \times E)$ & 0.689 & 117.368 & 0.000 \\
$T_{5}=24.702+(-5.818 \times E)$ & 0.769 & 176.067 & 0.000 \\
$T_{6}=27.146+(-5.682 \times E)$ & 0.844 & 286.484 & 0.000 \\
$T_{7}=28.599+(-6.121 \times E)$ & 0.883 & 398.768 & 0.000 \\
$T_{8}=28.211+(-6.171 \times E)$ & 0.906 & 512.496 & 0.000 \\
$T_{9}=26.435+(-6.309 \times E)$ & 0.892 & 436.805 & 0.000 \\
$T_{10}=24.081+(-6.376 \times E)$ & 0.811 & 227.461 & 0.000 \\
$T_{11}=21.238+(-6.686 \times E)$ & 0.766 & 173.500 & 0.000 \\
$T_{12}=18.501+(-6.881 \times E)$ & 0.734 & 145.890 & 0.000 \\
\hline
\end{tabular}


Table 11. The linear regression $(T=\alpha+\beta \times E)$ between monthly mean temperature $\left(T\right.$, in $\left.{ }^{\circ} \mathrm{C}\right)$ and elevation $(E$, in $\mathrm{km})$ in $\mathrm{Wr}(164$ stations). $\alpha$ is the intercept or temperature at sea level $\left({ }^{\circ} \mathrm{C}\right) ; \beta$ is the slope coefficient or TLR $\left({ }^{\circ} \mathrm{C} \mathrm{km}^{-1}\right)$.

\begin{tabular}{cccc}
\hline Regression formula $\boldsymbol{T}=\boldsymbol{\alpha}+\boldsymbol{\beta} \times \boldsymbol{E}$ & $\mathbf{R}^{2}$ & $\mathbf{F}$ & $\mathbf{p}$ \\
\hline$T_{1}=16.865+(-4.633 \times E)$ & 0.861 & 1006.073 & 0.000 \\
$T_{2}=17.520+(-4.570 \times E)$ & 0.816 & 719.816 & 0.000 \\
$T_{3}=20.051+(-4.612 \times E)$ & 0.806 & 671.836 & 0.000 \\
$T_{4}=23.573+(-5.127 \times E)$ & 0.885 & 1250.646 & 0.000 \\
$T_{5}=26.172+(-5.514 \times E)$ & 0.938 & 2437.335 & 0.000 \\
$T_{6}=27.811+(-5.590 \times E)$ & 0.969 & 5012.823 & 0.000 \\
$T_{7}=28.658+(-5.653 \times E)$ & 0.966 & 4616.954 & 0.000 \\
$T_{8}=28.349+(-5.629 \times E)$ & 0.966 & 4627.569 & 0.000 \\
$T_{9}=27.261+(-5.549 \times E)$ & 0.965 & 4449.861 & 0.000 \\
$T_{10}=25.103+(-5.247 \times E)$ & 0.934 & 2279.553 & 0.000 \\
$T_{11}=21.982+(-4.964 \times E)$ & 0.914 & 1721.928 & 0.000 \\
$T_{12}=18.590+(-4.746 \times E)$ & 0.892 & 1342.362 & 0.000 \\
\hline
\end{tabular}

Table 13. The linear regression $(T=\alpha+\beta \times E)$ between monthly mean temperature $\left(T\right.$, in $\left.{ }^{\circ} \mathrm{C}\right)$ and elevation $(E$, in $\mathrm{km})$ in $\mathrm{LWr}(129$ stations). $\alpha$ is the intercept or temperature at sea level $\left({ }^{\circ} \mathrm{C}\right) ; \beta$ is the slope coefficient or TLR $\left({ }^{\circ} \mathrm{C} \mathrm{km}^{-1}\right)$.

\begin{tabular}{rrrr}
\hline Regression formula $\boldsymbol{T}=\boldsymbol{\alpha}+\boldsymbol{\beta} \times \boldsymbol{E}$ & $\mathbf{R}^{2}$ & $\mathbf{F}$ & $\mathbf{p}$ \\
\hline$T_{1}=17.138+(-4.503 \times E)$ & 0.824 & 594.118 & 0.000 \\
$T_{2}=17.902+(-4.506 \times E)$ & 0.790 & 478.267 & 0.000 \\
$T_{3}=20.537+(-4.778 \times E)$ & 0.816 & 562.672 & 0.000 \\
$T_{4}=23.985+(-5.284 \times E)$ & 0.899 & 1130.193 & 0.000 \\
$T_{5}=26.456+(-5.670 \times E)$ & 0.938 & 1909.603 & 0.000 \\
$T_{6}=27.897+(-5.747 \times E)$ & 0.958 & 2916.292 & 0.000 \\
$T_{7}=28.597+(-5.750 \times E)$ & 0.954 & 2650.067 & 0.000 \\
$T_{8}=28.270+(-5.690 \times E)$ & 0.954 & 2608.238 & 0.000 \\
$T_{9}=27.346+(-5.583 \times E)$ & 0.953 & 2554.236 & 0.000 \\
$T_{10}=25.314+(-5.224 \times E)$ & 0.922 & 1499.289 & 0.000 \\
$T_{11}=22.220+(-4.798 \times E)$ & 0.902 & 1173.806 & 0.000 \\
\hline$T_{12}=18.813+(-4.533 \times E)$ & 0.864 & 803.631 & 0.000 \\
\hline
\end{tabular}

Table 12. The linear regression $(T=\alpha+\beta \times E)$ between monthly mean temperature $\left(T\right.$, in $\left.{ }^{\circ} \mathrm{C}\right)$ and elevation $(E$, in $\mathrm{km})$ in WWr (43 stations). $\alpha$ is the intercept or temperature at sea level $\left({ }^{\circ} \mathrm{C}\right) ; \beta$ is the slope coefficient or TLR $\left({ }^{\circ} \mathrm{C} \mathrm{km}^{-1}\right)$.

\begin{tabular}{cccc}
\hline Regression formula $\boldsymbol{T}=\boldsymbol{\alpha}+\boldsymbol{\beta} \times \boldsymbol{E}$ & $\mathbf{R}^{2}$ & $\mathbf{F}$ & $\mathbf{p}$ \\
\hline$T_{1}=16.157+(-5.914 \times E)$ & 0.843 & 220.322 & 0.000 \\
$T_{2}=16.377+(-5.725 \times E)$ & 0.861 & 253.857 & 0.000 \\
$T_{3}=18.543+(-5.061 \times E)$ & 0.785 & 149.601 & 0.000 \\
$T_{4}=21.443+(-5.022 \times E)$ & 0.895 & 351.190 & 0.000 \\
$T_{5}=24.095+(-5.251 \times E)$ & 0.930 & 546.651 & 0.000 \\
$T_{6}=26.809+(-5.372 \times E)$ & 0.906 & 397.379 & 0.000 \\
$T_{7}=28.380+(-5.926 \times E)$ & 0.922 & 486.028 & 0.000 \\
$T_{8}=28.050+(-6.025 \times E)$ & 0.925 & 503.021 & 0.000 \\
$T_{9}=26.098+(-6.003 \times E)$ & 0.945 & 700.807 & 0.000 \\
$T_{10}=23.564+(-5.914 \times E)$ & 0.899 & 365.130 & 0.000 \\
$T_{11}=20.598+(-6.128 \times E)$ & 0.904 & 385.357 & 0.000 \\
$T_{12}=17.779+(-6.260 \times E)$ & 0.886 & 319.735 & 0.000 \\
\hline
\end{tabular}

(a)

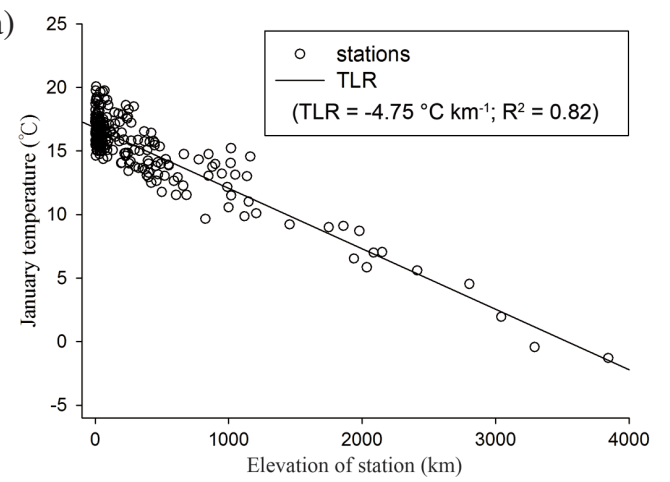

(b)

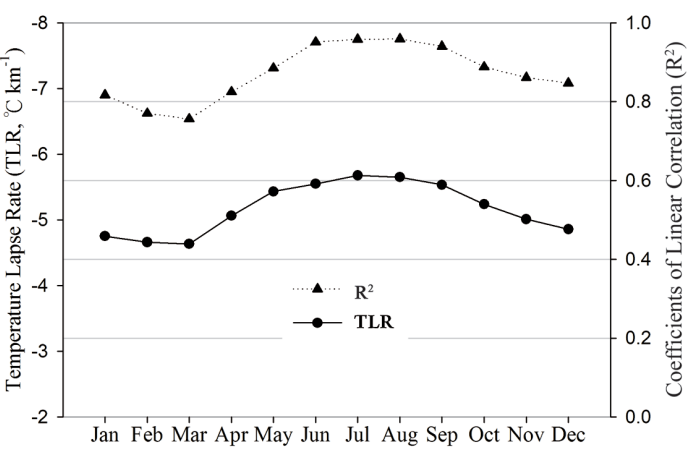

Fig. 2. (a) Elevation ( $E$, in $\mathrm{km})$ versus January mean temperature $\left(T\right.$, in $\left.{ }^{\circ} \mathrm{C}\right)$ for all stations $(\mathrm{n}=219)$ in the entire island region $(\mathrm{Ir})$ with a linear regression line. The regression equation, with the slope coefficient or temperature lapse rate $\left(\mathrm{TLR}=-4.75^{\circ} \mathrm{C} \mathrm{km}^{-1}\right)$ is $T=16.81-4.75 \times E\left(\mathrm{R}^{2}=0.82\right)$. (b) The monthly TLR in Ir ranges from -4.63 to $-5.68^{\circ} \mathrm{C} \mathrm{km}^{-1}$, and the $\mathrm{R}^{2}$ of the regression ranges from 0.76 to 0.96 . A steeper TLR occurred in the summer halfyear, whereas a shallower TLR occurred in the winter half-year. 
regions (red lines in Fig. 1b) into NWr, NEr, SWr, and SEr (Fig. 3a). The patterns of the TLR among different regions were not uniform (see the Supplementary Data in Table 3 - 13). The value ranges with the mean TLR were -5.65 to -4.17 (mean $\left.-4.92^{\circ} \mathrm{C} \mathrm{km}^{-1}\right)$ in $\mathrm{NWr},-6.26$ to $-5.02\left(-5.72^{\circ} \mathrm{C} \mathrm{km}^{-1}\right)$ in NEr, -6.51 to $-2.86\left(-4.94^{\circ} \mathrm{C} \mathrm{km}^{-1}\right)$ in $\mathrm{SWr}$, and -7.65 to -5.01 $\left(-6.40^{\circ} \mathrm{C} \mathrm{km}^{-1}\right)$ in $\mathrm{SEr}$ (Fig. 3b). We found that the annual amplitudes of TLR in NWr and NEr were smaller than those in SWr and SEr. The $\mathrm{R}^{2}$ of the regressions in NWr and NEr were greater than 0.79 , whereas a lower $\mathrm{R}^{2}$ values were found in SWr and SEr (Fig. 3c). The results suggest a stronger and more robust relationship between temperature and elevation in NWr and NEr than that in SWr and SEr throughout the year. Specifically, the linear regression model of the TLR in SEr was not statistically significant in the winter half-year (see Supplementary Table 7; p-values 0.065 to 0.139 ). The weaker relationship between temperature and elevation in the SEr was attributed to the insufficient number and nonhomogeneous distribution of stations, as Rolland (2003) and Burt and Holden (2010) concluded.

Figure 4a illustrates the areas covered by $\mathrm{Nr}$ and $\mathrm{Sr}$. The TLR ranged from -4.15 to $-5.63^{\circ} \mathrm{C} \mathrm{km}^{-1}$ in $\mathrm{Nr}$ and -2.90 to $-6.47^{\circ} \mathrm{C} \mathrm{km}^{-1}$ in $\mathrm{Sr}$ (Fig. 4b). The monthly patterns of the TLR in both $\mathrm{Nr}$ and $\mathrm{Sr}$ were steeper during the summer half-year than during the winter half-year. These results agreed with the TLR over the entire island (Fig. 2b) and other studies (e.g., Blandford et al. 2008; Minder et al. 2010). The annual means of the TLR in $\mathrm{Nr}$ and $\mathrm{Sr}$ were nearly equal $\left(-4.88^{\circ} \mathrm{C} \mathrm{km}^{-1}\right.$ vs. $\left.-4.98^{\circ} \mathrm{C} \mathrm{km}^{-1}\right)$. However, the annual amplitude of the TLR in Sr was much greater than that in Nr. The TLR in Nr was shallower than that in Sr during the summer half-year, whereas an opposite relation was observed during the winter half-year. It was notable that the TLR in Sr during the winter half-year was unusually shallow and accompanied by a particularly low $\mathrm{R}^{2}$ (Fig. 4c). Thus, high uncertainties occurred in Sr during the winter half-year.

Figure 5a illustrates the areas covered by $\mathrm{Er}$ and $\mathrm{Wr}$. The TLR ranged from -5.68 to $-6.88^{\circ} \mathrm{C} \mathrm{km}^{-1}$ in $\mathrm{Er}$ and from -4.57 to $-5.65^{\circ} \mathrm{C} \mathrm{km}^{-1}$ in $\mathrm{Wr}$ (Fig. 5b). The monthly and average TLR in $\operatorname{Er}\left(\right.$ mean $\left.-6.23^{\circ} \mathrm{C} \mathrm{km}^{-1}\right)$ were obviously steeper than that in $\mathrm{Wr}\left(\right.$ mean $\left.-5.15^{\circ} \mathrm{C} \mathrm{km}^{-1}\right)$. By comparison, the seasonal pattern of the TLR in Wr was similar to Ir (Fig. 2b), but Er had an opposite pattern. This significant difference of the TLR on opposite slopes had also been noted in other references (e.g., Barry 1992; Loope and Giambelluca 1998; Tang and Fang 2006; Urrutia and Vuille 2009). The $\mathrm{R}^{2}$ of the regression in $\mathrm{Wr}$ was higher and more robust than that in Er (Fig. 5c). Higher uncertainties occurred in Er, especially during the winter half-year.

To make a comprehensive comparison of the TLR in the different geographical regions in Taiwan (Figs. 2 - 5), some characteristics of the TLR had to be made clear. First, (a)

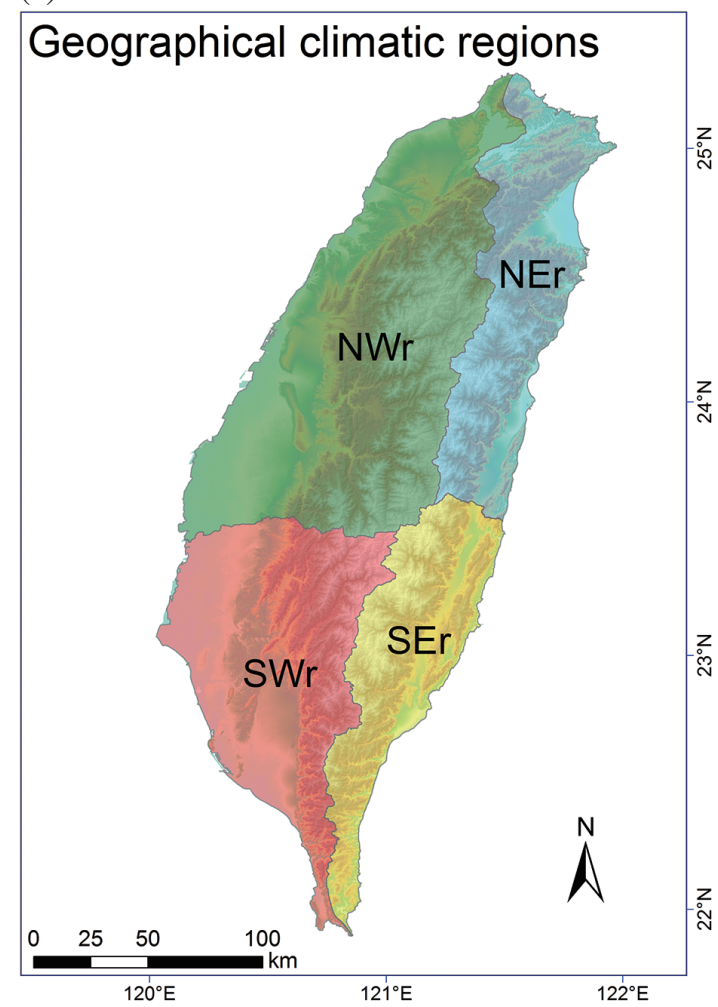

(b)

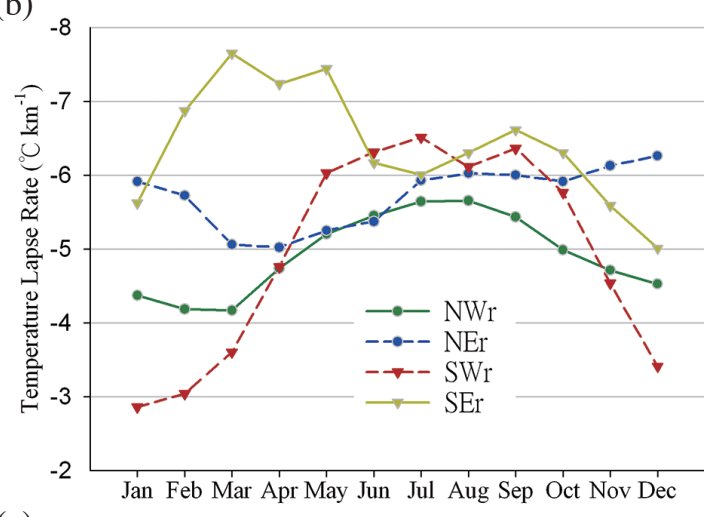

(c)

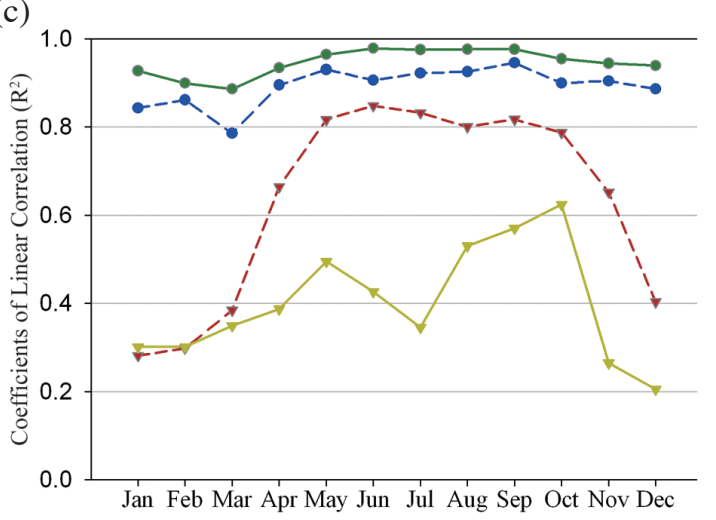

Fig. 3. (a) Areas covered by the northwest (NWr), northeast (NEr), southwest (SWr), and southeast (SEr) regions; (b) monthly variations of the temperature lapse rate $\left(\mathrm{TLR},{ }^{\circ} \mathrm{C} \mathrm{km}^{-1}\right)$; (c) coefficient of determination $\left(\mathrm{R}^{2}\right)$ of linear regression. 
(a)

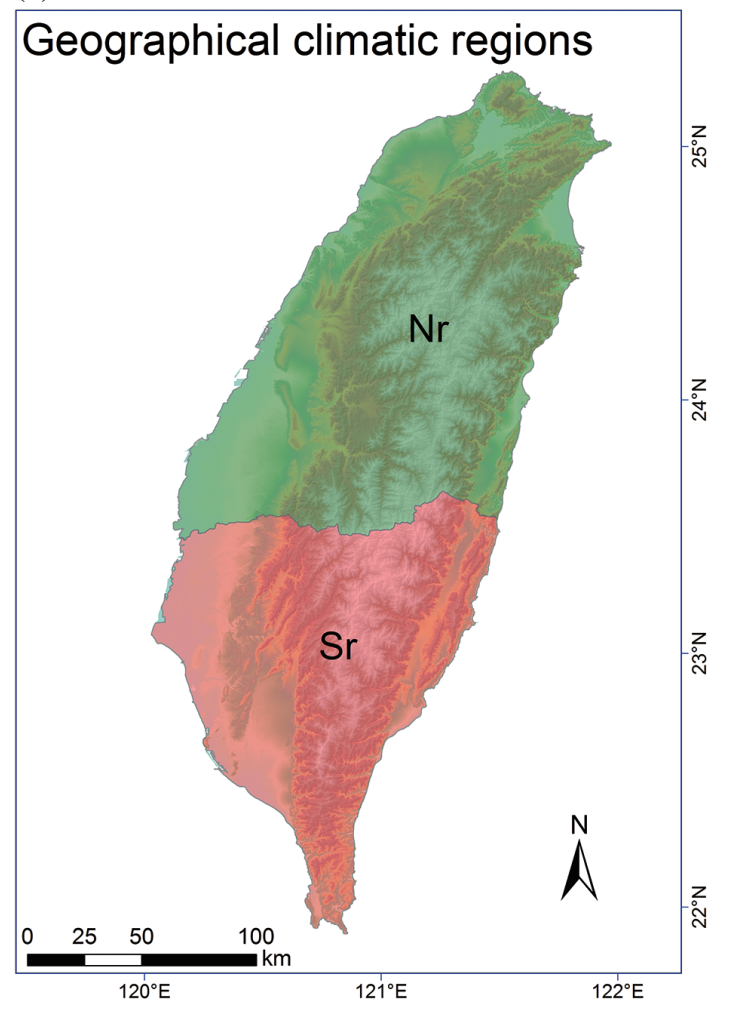

(b)

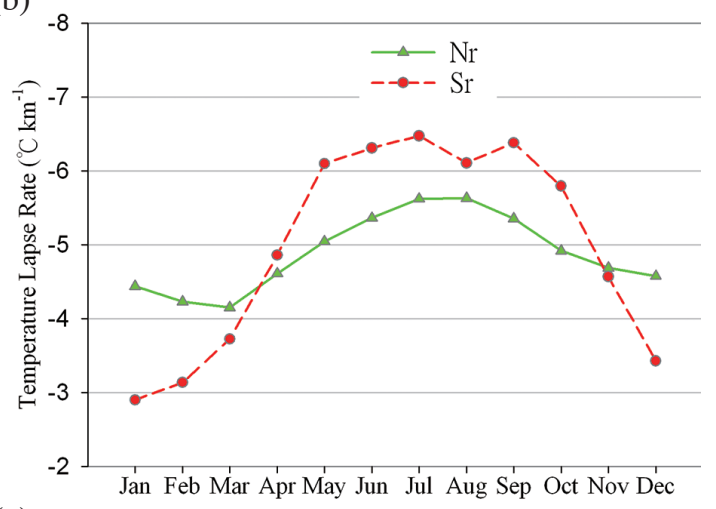

(c)

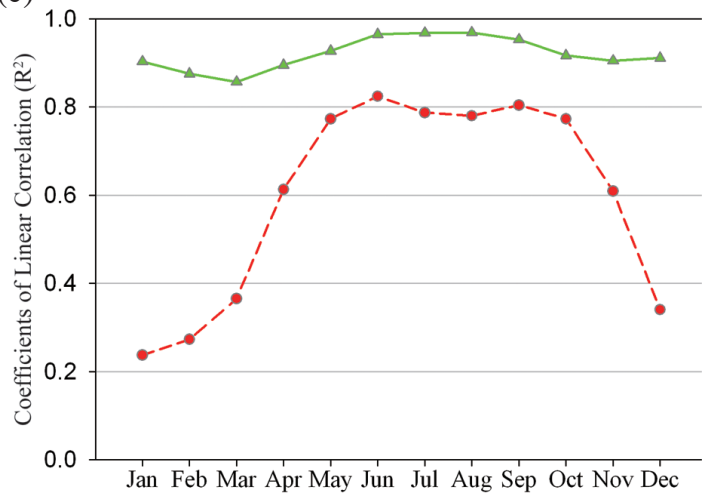

Fig. 4. (a) Areas covered by the north $(\mathrm{Nr}=\mathrm{NWr}+\mathrm{NEr})$ and south $(\mathrm{Sr}=\mathrm{SWr}+\mathrm{SEr})$ regions; (b) monthly variations of the temperature lapse rate (TLR, $\left.{ }^{\circ} \mathrm{C} \mathrm{km}^{-1}\right)$; (c) coefficient of determination $\left(\mathrm{R}^{2}\right)$ of linear regression.

(a)

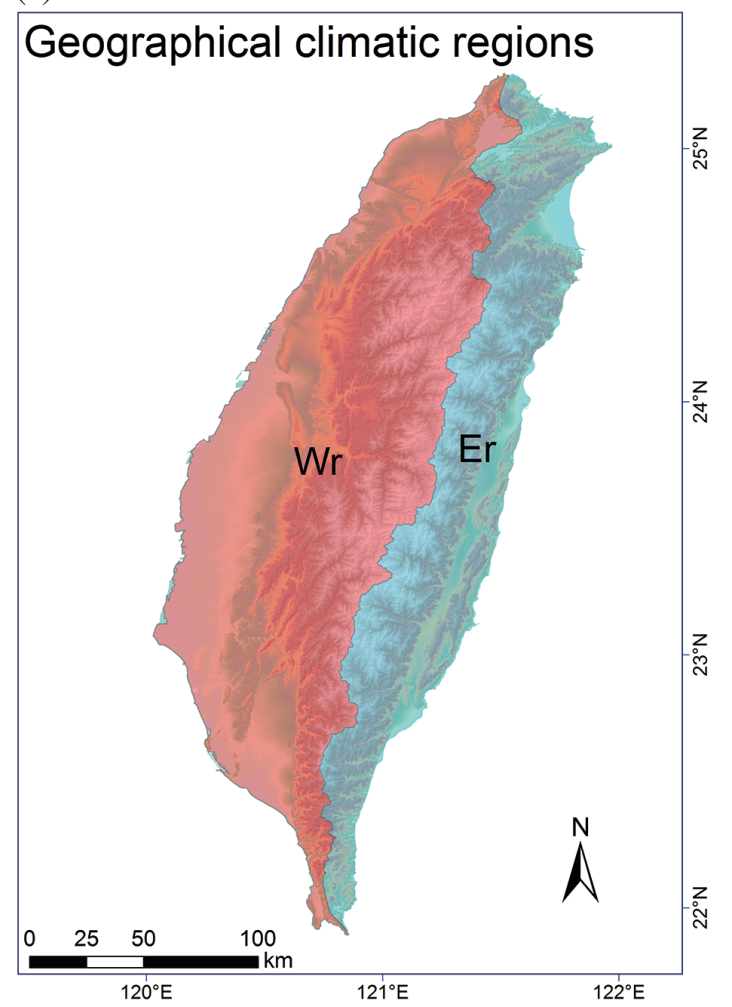

(b)

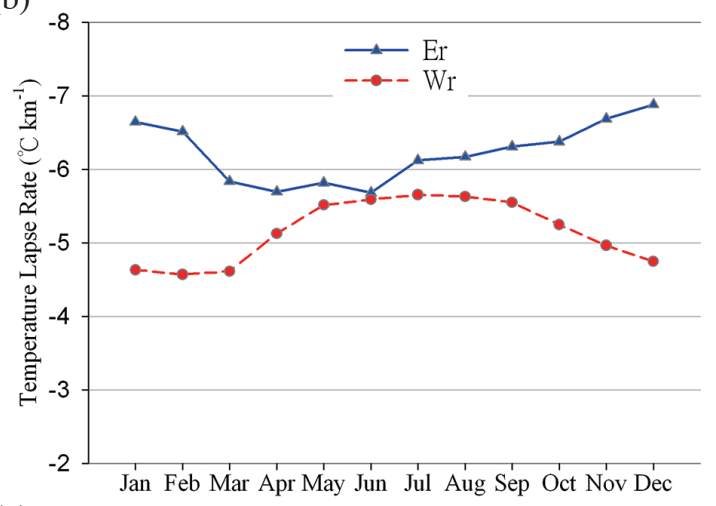

(c)

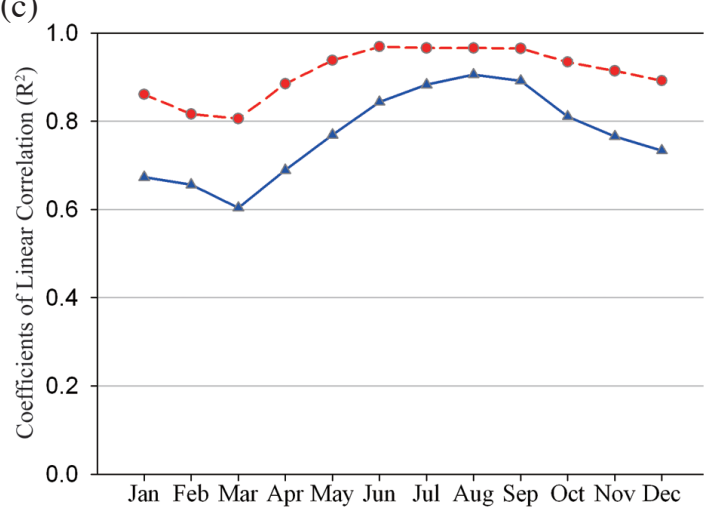

Fig. 5. (a) Areas covered by the west $(\mathrm{Wr}=\mathrm{NWr}+\mathrm{SWr})$ and east $(\mathrm{Er}=\mathrm{NEr}+\mathrm{SEr})$ regions; (b) monthly variations of the temperature lapse rate $\left(\mathrm{TLR},{ }^{\circ} \mathrm{C} \mathrm{km}{ }^{-1}\right)$; (c) coefficient of determination $\left(\mathrm{R}^{2}\right)$ of linear regression. 
the steeper TLR during the summer half-year and the shallower TLR during the winter half-year were the synoptically seasonal patterns. Second, the spatio-temporal patterns of the TLR varied greatly across the different geographical regions of Taiwan. Consequently, the variations of the TLR among the different regions imply that the use of a constant, or socalled standard TLR, such as -6.0 or $-6.5^{\circ} \mathrm{C} \mathrm{km}^{-1}$ (e.g., Willmott and Matsuura 2001; Asaoka and Kominami 2012; Samanta et al. 2012) is unjustifiable when predicting full-scale temperatures, especially in complex terrains and under monsoon conditions, as in Taiwan. For example, air temperature of Mt. Yushan weather station (in Wr, 3845 m a.s.l.) in January was $-0.94^{\circ} \mathrm{C}$ derived from our local TLR of $-4.63^{\circ} \mathrm{C} \mathrm{km}^{-1}$ or $-8.13^{\circ} \mathrm{C}$ derived from standard TLR of $-6.5^{\circ} \mathrm{C} \mathrm{km}^{-1}$. Our estimated value was closer to the true temperature of $-1.1^{\circ} \mathrm{C}$ observed by the Central Weather Bureau (http://www.cwb. gov.tw/V7e/climate/monthlyMean/tx.htm).

During the winter half-year, the phenomenon of steeper TLR in Er (Figs. 5b, c), shallower TLR in Sr (Figs. 4b, c) and especially shallower TLR in SWr (Fig. 3b) are quite interesting. Since the SWr is on the leeward side of the CMR or rain-shadow region of the prevailing northeast monsoon during the winter half-year, the effect of the prevailing northeast monsoon and CMR blocking effect on the TLR will be further examined in following subsection.

(a)

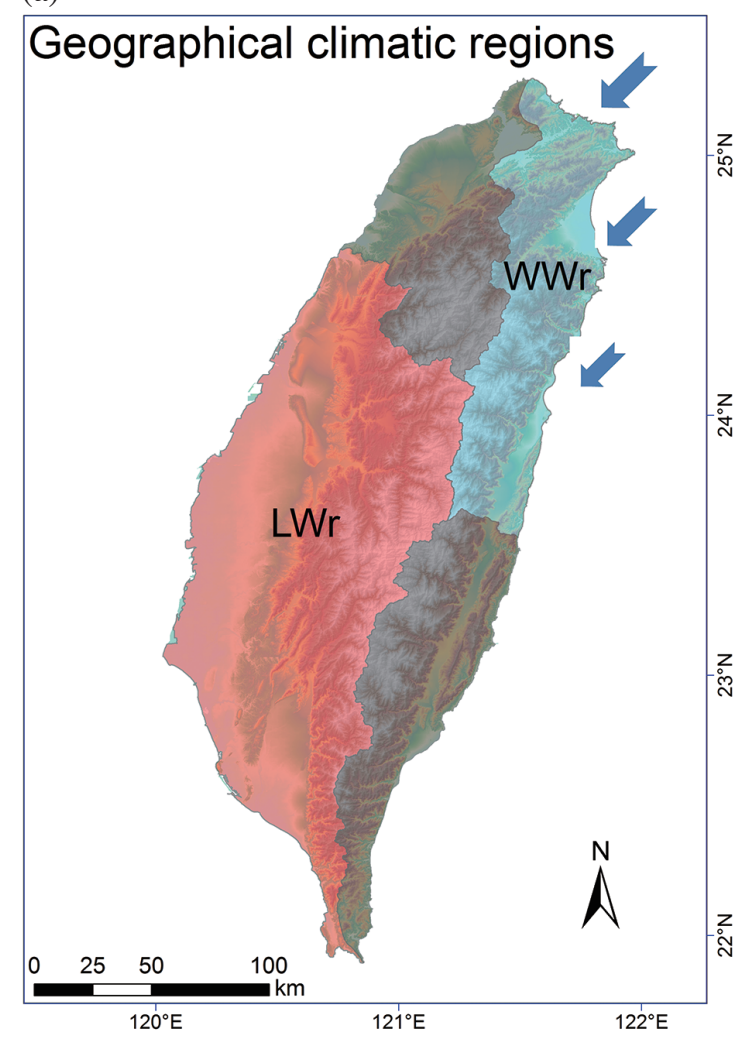

\subsection{Effect of the Prevailing Northeast Monsoon and Terrain Blocking on the TLR}

Minder et al. (2010) found the seasonal pattern of the TLR was opposite between the windward and leeward sides of mountainous terrain. To understand the effect of the prevailing northeast monsoon and the topographic effect of the CMR on the TLR, we divided Taiwan into LWr and WWr (Fig. 6a) by using the suggestions of $\mathrm{Su}$ (1985) and Chiu et al. (2009). The range of values of the TLR was -4.50 to $-5.75^{\circ} \mathrm{C} \mathrm{km}^{-1}$ (mean $-5.17^{\circ} \mathrm{C} \mathrm{km}^{-1}$ ) in $\mathrm{LWr}$ and -5.02 to $-6.26^{\circ} \mathrm{C} \mathrm{km}^{-1}$ (mean $-5.72^{\circ} \mathrm{C} \mathrm{km}^{-1}$ ) in WWr (Fig. 6b). During the prevailing northeast monsoon season (winter), the TLR exhibits a more obvious contrast between $\mathrm{LWr}$ (shallower, $-4.51^{\circ} \mathrm{C} \mathrm{km}^{-1}$ ) and $\mathrm{WWr}$ (steeper, $-5.97^{\circ} \mathrm{C} \mathrm{km}^{-1}$ ). Figure $6 \mathrm{c}$ displays the $\mathrm{R}^{2}$ of regression formulas of these two regions. The spatio-temporal pattern of the TLR between LWr and WWr was obviously different. The TLR in LWr was steeper during the summer halfyear and shallower during the winter half-year, in agreement with the general tendency of the TLR, as shown in Fig. 2b. Due to the monsoon cold air flow approaching the WWr region in wintertime, onshore stratus clouds might assist in making the TLR shallower within the LWr. The hydrological characteristics at NEr and $\mathrm{SWr}$ are shown in Fig. 3. NEr is the ever-wet climate type, and SWr is the summer-rain climate

(b)

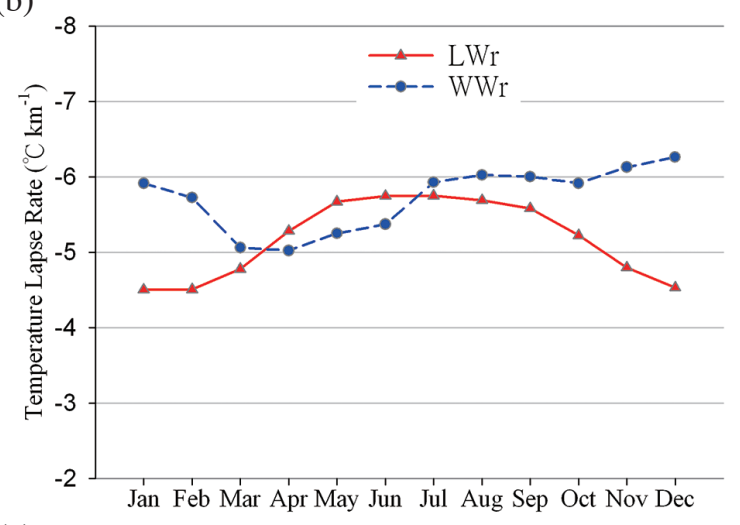

(c)

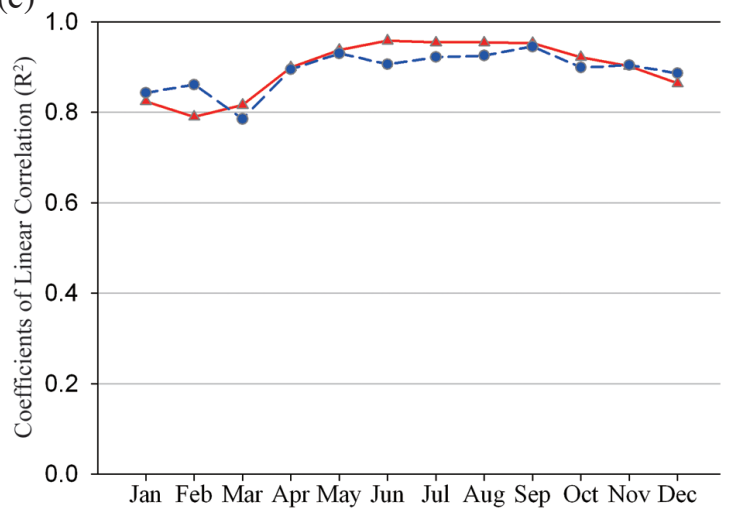

Fig. 6. (a) Areas covered by leeward (LWr) and windward (WWr) regions; (b) monthly variations of the temperature lapse rate $\left(\mathrm{TLR},{ }^{\circ} \mathrm{C} \mathrm{km}{ }^{-1}\right)$; (c) coefficient of determination $\left(\mathrm{R}^{2}\right)$ of linear regression. 
type (Su 1985). The precipitation in NEr during the winter half-year accounted for $41.79 \%$ of the annual precipitation; by contrast, that in SWr was only 10.55\% (Chiu et al. 2009). Thus, under the prevailing northeast monsoon during winter, NEr was representative of windward and moist conditions, while SWr of leeward and dry conditions. So the WWr-LWr TLR pattern in Fig. 6b is similar to the SWr-NEr pattern in Fig. 3b.
Chang et al. (2011) used 4-year (2006 - 2009) MTSAT (Japanese geostationary weather satellite) daytime satellite visible images with $1-\mathrm{km}$ resolution to retrieve the daytime cloud amount (the frequency of the cloud cover) surrounding Taiwan. The monthly-mean cloud amount contour is reprocessed into Fig. 7. In January, the high cloud amount (>60\%) region on the windward side of the CMR is clearly different from the low cloud amount $(<35 \%)$ regions on land located (a)

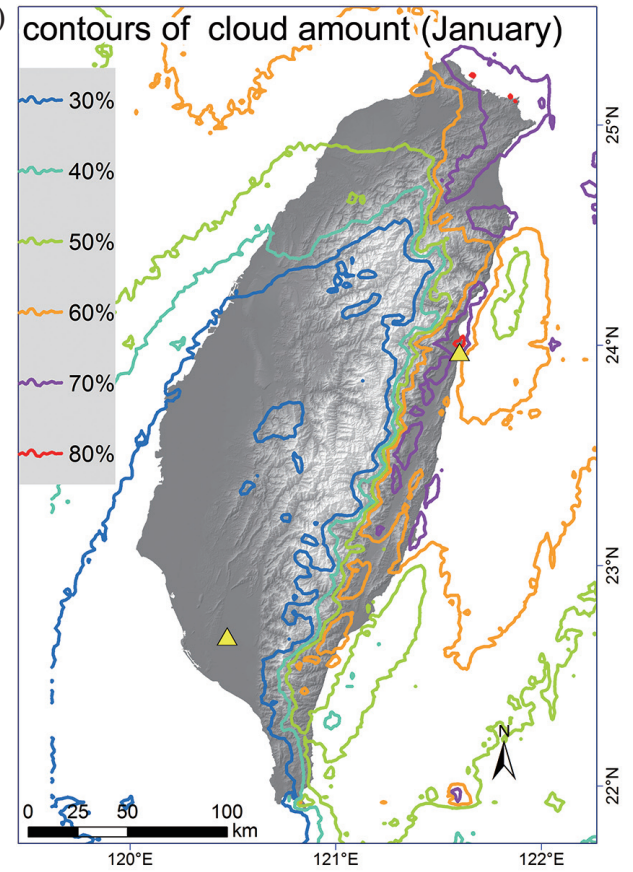

(b)

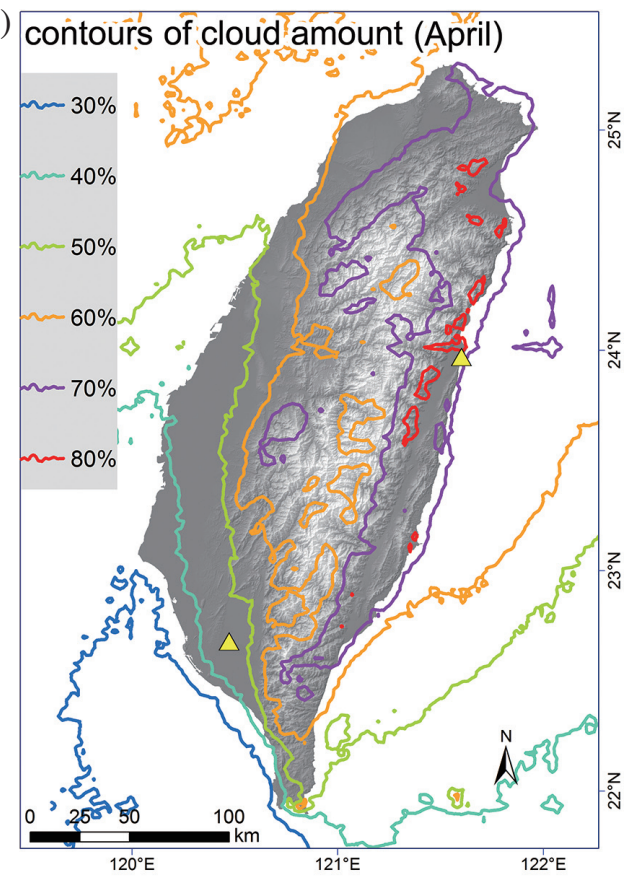

(c)

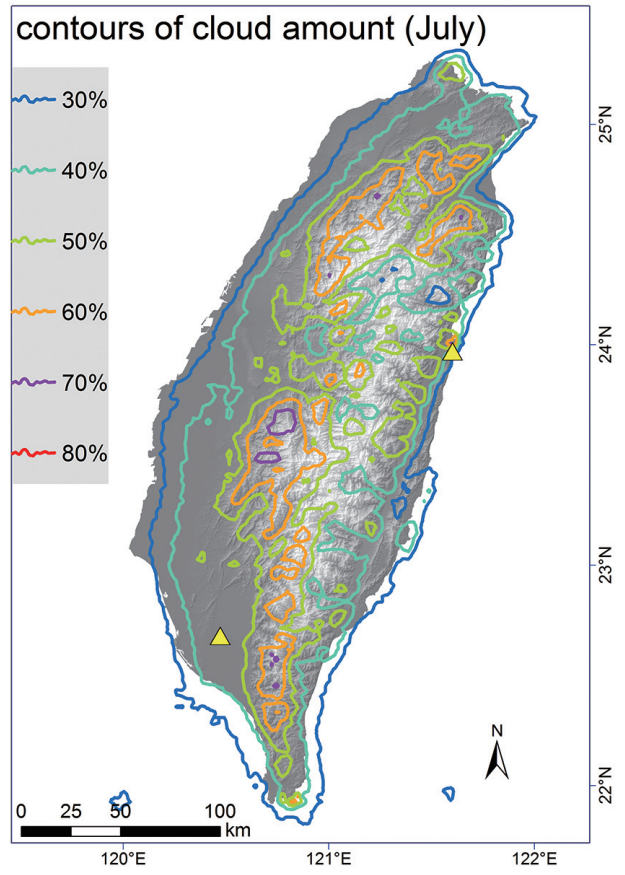

(d)

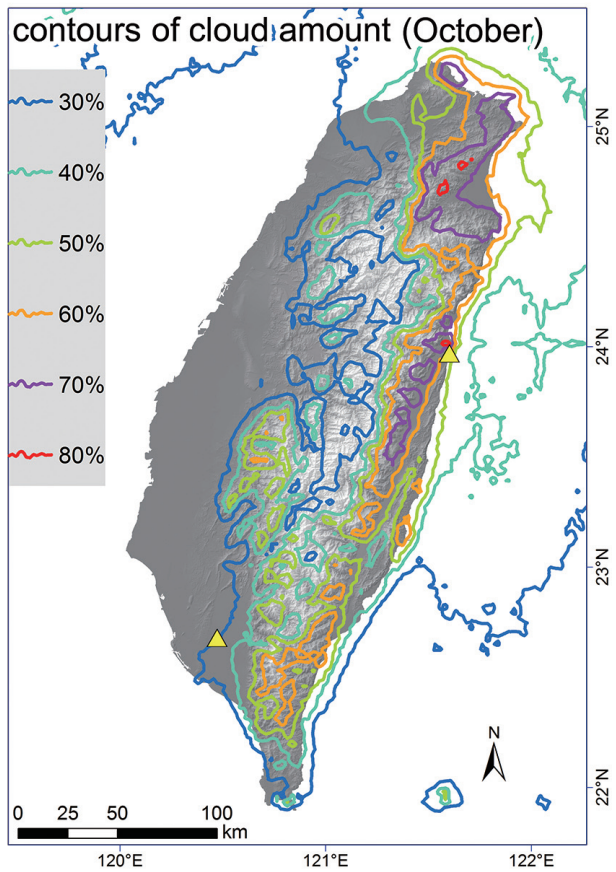

Fig. 7. Monthly-mean daytime cloud amount surrounding Taiwan in January, April, July, and October (contour unit: \%). These diagrams were reprocessed from the work of Chang et al. (2011), who used MTSAT 1-km resolution daytime visible images from 2006 to 2009. 
in SWr and around mountain peaks of over 3000 m elevation. But this spatial contrast of cloud amount disappears in July. During the southwestern monsoon season (shown in Fig. 1d), stronger solar heating causes local land-sea circulation and makes cloudy land with cloudless ocean during summertime. We analyzed the daily balloon-sounding data (Vaisala RS 92 radiosonde) operated by CWB Hualien weather stations and the Chinese Air Force Pingtung airport (shown in Fig. 1b) to identify the vertical temperature and wind profiles from the ground to 4000 m elevation in all months of 2012 in Taiwan (Lin and Lu 2013). Comparing the relative humidity profiles in Hualien (windward side, NEr) and Pingtung (leeward side, $\mathrm{SWr}$ ) in January (Figs. 8a, b), the former is more humid in the lower atmosphere below $2000 \mathrm{~m}$ elevation. A slight change of air temperature slope could also be found at about $2000 \mathrm{~m}$ elevation. The transition layer between the lower north-eastern wind monsoon flow and the higher western flow was lo- cated at about $2500 \mathrm{~m}$ height at Hualien and $1500 \mathrm{~m}$ height at Pingtung from the wind-field profiles. The wind speed below this transition layer at Pingtung is small and traps a temperature inversion layer at about $500 \mathrm{~m}$ elevation. Our explanation is that the CMR blocks colder and wet Siberian monsoon air flow on the windward side (NEr) during wintertime, and low stratus cloud within this region makes TLR steeper than during springtime (shown in Fig. 6b). Furthermore, the CMR blocks this cold monsoon flow efficiently to provide the calm, dry air and temperature inversion layer on the leeward side. This terrain-block feature also makes the TLR shallower that on the windward side. During July, summer south-western monsoon flow dominates the wind pattern over Taiwan and makes the transition layer of wind direction disappear (Figs. 8c - d). The relative humidity profile at Hualien shows a more humid layer below about $1300 \mathrm{~m}$ elevation and the top of mixing layer occurs at about $2500 \mathrm{~m}$. The mixing layer of relative
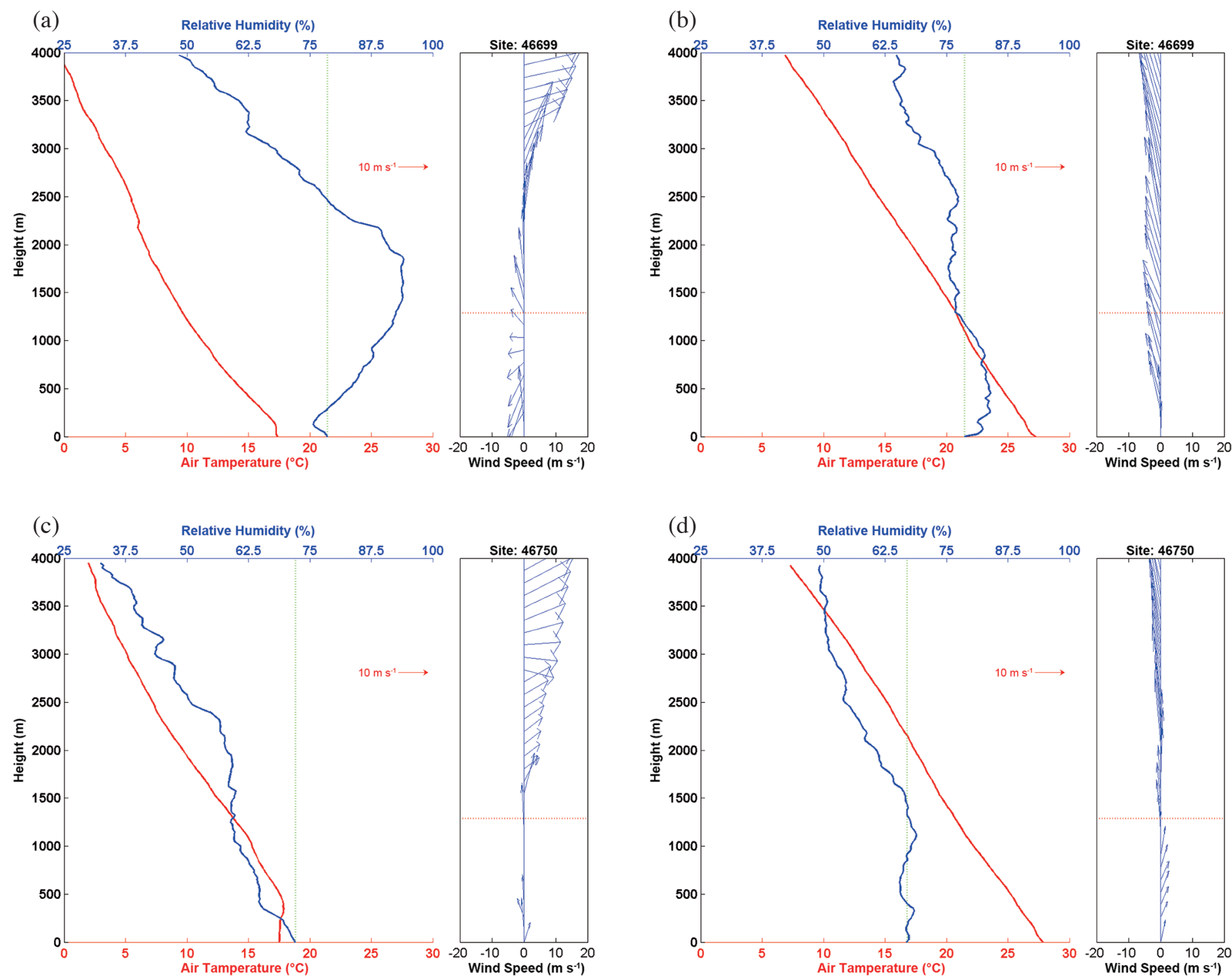

Fig. 8. Monthly means of temperature (red line), relative humidity (blue line) and wind field profiles at Hualien and Pingtung balloon radiosonde sites in January and July. The red dash line marks the transition layer of wind direction, and the green dash line is the reference line of the relative humidity at ground level. 
humidity at Pingtung is at about 1500 m elevation in summertime. These features, including the cloud cover in July (Fig. 7), cause cloudy land influenced by local land-sea circulation and the thermal convection effect during the summer monsoon flow; the result is similarity of the TLR at SWr and NEr in July.

\section{CONCLUSIONS}

This study comprehensively explored the spatiotemporal changes of TLR in a subtropical island (Taiwan) with complex topography whose weather is influenced by the prevailing winter monsoon. The average TLR for the entire island was $-5.17{ }^{\circ} \mathrm{C} \mathrm{km}^{-1}$. The seasonal pattern of the TLR exhibited a general tendency: steeper in summer and shallower in winter. Our analysis in section 3 showed that changes of the TLR varied by region and season. The results also confirmed that a steeper TLR occurred on the windward side of the CMR during the winter monsoon, accompanied by a shallower TLR on the leeward side. This result contradicts the common tendency of the TLR to change from approximately $-9.8^{\circ} \mathrm{C} \mathrm{km}^{-1}$ in dry conditions to approximately $-4.0^{\circ} \mathrm{C} \mathrm{km}^{-1}$ in saturated conditions (Barry and Chorely 2009). From the analysis of cloud amount and vertical profiles of radiosonde observations in January and July, we explain the steeper TLR in the windward NEr and the shallower TLR in the leeward SWr during the winter monsoon as being caused by the CMR blocking effect. The contrasting behavior of the TLR is related to the onshore thick (500 - $2500 \mathrm{~m}$ depth) stratus clouds in the cold Siberian monsoon air on the windward side of the CMR. On the southwestern leeward side of the CMR, the low-level $(1500 \mathrm{~m})$ weak ventilation and temperature inversion make the TLR shallower than on the windward side. During the summer monsoon season, the thermal heating on the CMR slopes and land-sea air circulation provide the mixing required for cumulus cloud development. Cumulus cloud replaces stratus cloud and makes the TLR steeper in the NEr, causing the low-level temperature inversion to disappear within the SWr.

In conclusion, using a temporally constant and spatially uniform TLR to predict full-scale temperature was found to be unjustified. Although many studies often use the standard TLR of -6.0 or $-6.5^{\circ} \mathrm{C} \mathrm{km}^{-1}$, it is nothing more than a rough or global average. The TLR varies spatio-temporally, especially in a monsoon cloudy environment influenced by mountain terrain like Taiwan.

Acknowledgements This work was supported by SheiPa National Park and the Experimental Forest of National Chung Hsing University. The authors also appreciate the MTSAT cloud amount data sharing from Prof. Hsien-Kuo Chang, National Chiao-Tung University and the constructive comments of the reviewers.

\section{REFERENCES}

Araguás-Araguás, L., K. Froehlich, and K. Rozanski, 1998: Stable isotope composition of precipitation over southeast Asia. J. Geophys. Res., 103, 28721-28742, doi: 10.1029/98JD02582. [Link]

Asaoka, Y. and Y. Kominami, 2012: Spatial snowfall distribution in mountainous areas estimated with a snow model and satellite remote sensing. Hydrol. Res. Lett., 6, 1-6, doi: 10.3178/HRL.6.1. [Link]

Barry, R. G., 1992: Mountain Weather and Climate, Routledge, New York, 402 pp.

Barry, R. G. and R. J. Chorley, 2009: Atmosphere, Weather and Climate, $9^{\text {th }}$ edition, Routledge, London, $536 \mathrm{pp}$.

Bertoldi, G., C. Notarnicola, G. Leitinger, S. Endrizzi, M. Zebisch, S. D. Chiesa, and U. Tappeiner, 2010: Topographical and ecohydrological controls on land surface temperature in an alpine catchment. Ecohydrology, 3, 189-204, doi: 10.1002/eco.129. [Link]

Bhattarai, K. R., O. R. Vetaas, and J. A. Grytnes, 2004: Fern species richness along a central Himalayan elevational gradient, Nepal. J. Biogeogr., 31, 389-400, doi: 10.1046/j.0305-0270.2003.01013.x. [Link]

Blandford, T. R., K. S. Humes, B. J. Harshburger, B. C. Moore, V. P. Walden, and H. Ye, 2008: Seasonal and synoptic variations in near-surface air temperature lapse rates in a mountainous basin. J. Appl. Meteorol. Climatol., 47, 249-261, doi: 10.1175/2007JAMC1565.1. [Link]

Bolstad, P. V., L. Swift, F. Collins, and J. Régnière, 1998: Measured and predicted air temperatures at basin to regional scales in the southern Appalachian mountains. Agric. For. Meteorol., 91, 161-176, doi: 10.1016/ S0168-1923(98)00076-8. [Link]

Burt, T. P. and J. Holden, 2010: Changing temperature and rainfall gradients in the British Uplands. Clim. Res., 45, 57-70, doi: 10.3354/cr00910. [Link]

Cannon, A. J., D. Neilsen, and B. Taylor, 2012: Lapse rate adjustments of gridded surface temperature normals in an area of complex terrain: Atmospheric reanalysis versus statistical up-sampling. Atmos.-Ocean., 50, 9-16, doi: 10.1080/07055900.2011.649035. [Link]

Chang, H. K., W. W. Chen, and J. C. Liou, 2011: The cloud distribution and optical satellite image availability rate analysis in Taiwan. Proceedings of the $33^{\text {rd }}$ Ocean Engineering Conference in Taiwan, National Kaohsiung Marine University, Kaohsiung, Taiwan, 699-704. (in Chinese)

Chiou, C. R., G. Z. M. Song, J. H. Chien, C. F. Hsieh, J. C. Wang, M. Y. Chen, H. Y. Liu, C. L. Yeh, Y. J. Hsia, and T. Y. Chen, 2010: Altitudinal distribution patterns of plant species in Taiwan are mainly determined by the northeast monsoon rather than the heat retention mechanism of Massenerhebung. Bot. Stud., 51, 89-97. 
Chiu, C. A., P. H. Lin, and K. C. Lu, 2009: GIS-based tests for quality control of meteorological data and spatial interpolation of climate data. Mt. Res. Dev., 29, 339349, doi: 10.1659/mrd.00030. [Link]

Daly, C., M. Halbleib, J. I. Smith, W. P. Gibson, M. K. Doggett, G. H. Taylor, J. Curtis, and P. P. Pasteris, 2008: Physiographically sensitive mapping of climatological temperature and precipitation across the conterminous United States. Int. J. Climatol., 28, 2031-2064, doi: 10.1002/joc.1688. [Link]

Doran, P. T., C. P. McKay, G. D. Clow, G. L. Dana, A. G. Fountain, T. Nylen, and W. B. Lyons, 2002: Valley floor climate observations from the McMurdo dry valleys, Antarctica, 1986-2000. J. Geophys. Res., 107, doi: 10.1029/2001JD002045. [Link]

Elith, J. and J. R. Leathwick, 2009: Species distribution models: Ecological explanation and prediction across space and time. Annu. Rev.Ecol.Evol.S., 40, 677-697, doi: 10.1146/annurev .ecolsys.110308.120159. [Link]

Guan, B. T., H. W. Hsu, T. H. Wey, and L. S. Tsao, 2009: Modeling monthly mean temperatures for the mountain regions of Taiwan by generalized additive models. Agric. For. Meteorol., 149, 281-290, doi: 10.1016/j. agrformet.2008.08.010. [Link]

Guisan, A. and N. E. Zimmermann, 2000: Predictive habitat distribution models in ecology. Ecol.Model., 135, 147186, doi: 10.1016/S0304-3800(00)00354-9. [Link]

Huang, S., P. M. Rich, R. L. Crabtree, C. S. Potter, and P. $\mathrm{Fu}, 2008$ : Modeling monthly near-surface air temperature from solar radiation and lapse rate: Application over complex terrain in Yellowstone National Park. Phys. Geogr., 29, 158-178.

Jobbágy, E. G. and R. B. Jackson, 2000: Global controls of forest line elevation in the northern and southern hemispheres. Glob. Ecol. Biogeogr., 9, 253-268, doi: 10.1046/j.1365-2699.2000.00162.x. [Link]

Kirchner, M., T. Faus-Kessler, G. Jakobi, M. Leuchner, L. Ries, H. E. Scheel, and P. Suppan, 2013: Altitudinal temperature lapse rates in an Alpine valley: Trends and the influence of season and weather patterns. Int. J. Climatol., 33, 539-555, doi: 10.1002/joc.3444. [Link]

Kitayama, K., 1992: An altitudinal transect study of the vegetation on Mount Kinabalu, Borneo. Vegetatio, 102, 149-171, doi: 10.1007/BF00044731. [Link]

Komatsu, H., H. Hashimoto, T. Kume, N. Tanaka, N. Yoshifuji, K. Otsuki, M. Suzuki, and T. Kumagai, 2010: Modeling seasonal changes in the temperature lapse rate in a northern Thailand mountainous area. J. Appl. Meteorol. Climatol., 49, 1233-1246, doi: 10.1175/2010JAMC2297.1. [Link]

Lenoir, J., J. C. Gégout, P. A. Marquet, P. de Ruffray, and H. Brisse, 2008: A significant upward shift in plant species optimum elevation during the 20th century. Science, 320, 1768-1771, doi: 10.1126/science.1156831. [Link]
Leuschner, C., 2000: Are high elevations in tropical mountains arid environments for plants? Ecology, 81, 1425-1436, doi: 10.1890/0012-9658(2000)081[1425: AHEITM]2.0.CO;2. [Link]

Lin, P. H. and C. Y. Lu, 2013: The multi-layer feature of atmospheric boundary layer surrounding a subtropical monsoon island. 93 ${ }^{\text {rd }}$ AMS Annual Meeting, Austin, U.S.A.

Lin, C. Y., S. C. C. Lung, H. R. Guo, P. C. Wu, and H. J. Su, 2009: Climate variability of cold surge and its impact on the air quality of Taiwan. Clim. Change, 94, 457471, doi: 10.1007/s10584-008-9495-9. [Link]

Loope, L. L. and T. W. Giambelluca, 1998: Vulnerability of island tropical montane cloud forests to climate change, with special reference to East Maui, Hawaii. Clim. Change, 39, 503-517, doi: 10.1023/A:1005372118420. [Link]

Minder, J. R., P. W. Mote, and J. D. Lundquist, 2010: Surface temperature lapse rates over complex terrain: Lessons from the Cascade Mountains. J. Geophys. Res., 115, D14122, doi: 10.1029/2009JD013493. [Link]

Peng, T. R., C. H. Wang, C. C. Huang, L. Y. Fei, C. T. A. Chen, and J. L. Hwong, 2010: Stable isotopic characteristic of Taiwan's precipitation: A case study of western Pacific monsoon region. Earth Planet. Sci. Lett., 289, 357-366, doi: 10.1016/j.epsl.2009.11.024. [Link]

Pepin, N., 2001: Lapse rate changes in northern England. Theor. Appl. Climatol., 68, 1-16, doi: 10.1007/ s007040170049. [Link]

Prentice, I. C., W. Cramer, S. P. Harrison, R. Leemans, R. A. Monserud, and A. M. Solomon, 1992: A global biome model based on plant physiology and dominance, soil properties and climate. J. Biogeogr., 19, 117-134.

Rolland, C., 2003: Spatial and seasonal variations of air temperature lapse rates in alpine regions. J. Climate, 16, 1032-1046, doi: 10.1175/1520-0442(2003)016<1032: SASVOA $>2.0 . C O ; 2$. [Link]

Running, S. W., R. R. Nemani, and R. D. Hungerford, 1987: Extrapolation of synoptic meteorological data in mountainous terrain and its use for simulating forest evapotranspiration and photosynthesis. Can. J. Forest Res., 17, 472-483, doi: 10.1139/x87-081. [Link]

Samanta, S., D. K. Pal, D. Lohar, and B. Pal, 2012: Interpolation of climate variables and temperature modeling. Theor. Appl. Climatol., 107, 35-45, doi: 10.1007/ s00704-011-0455-3. [Link]

Stahl, K., R. D. Moore, J. A. Floyer, M. G. Asplin, and I. G. McKendry, 2006: Comparison of approaches for spatial interpolation of daily air temperature in a large region with complex topography and highly variable station density. Agric. For. Meteorol., 139, 224-236, doi: 10.1016/j.agrformet.2006.07.004. [Link]

Stutter, M. I., L. K. Deeks, D. Low, and M. F. Billett, 2006: Impact of soil and groundwater heterogeneity on surface 
water chemistry in an upland catchment. J. Hydrol., 318, 103-120, doi: 10.1016/j.jhydrol.2005.06.007. [Link]

$\mathrm{Su}$, H. J., 1984a: Studies on the climate and vegetation types of the natural forests in Taiwan (I). Analysis of the variation in climate factors. Q. J. Chinese For., 17, 1-14.

Su, H. J., 1984b: Studies on the climate and vegetation types of the natural forests in Taiwan (II). Altitudinal vegetation zone in relation to temperature gradient. Q.J. Chinese For., 17, 57-73.

Su, H. J., 1985: Studies on the climate and vegetation types of the natural forests in Taiwan (III). A scheme of geographical climate regions. Q. J. Chinese For., 18, 33-44.

Tang, C. Q., 2006: Forest vegetation as related to climate and soil conditions at varying altitudes on a humid subtropical mountain, Mount Emei, Sichuan, China. Ecol. Res., 21, 174-180, doi: 10.1007/s11284-005-0106-1. [Link]

Tang, Z. and J. Fang, 2006: Temperature variation along the northern and southern slopes of Mt. Taibai, China.
Agric. For. Meteorol., 139, 200-207, doi: 10.1016/j. agrformet.2006.07.001. [Link]

Trivedi, M. R., P. M. Berry, M. D. Morecroft, and T. P. Dawson, 2008: Spatial scale affects bioclimate model projections of climate change impacts on mountain plants. Global Change Biol., 14, 1089-1103, doi: 10.1111/j.1365-2486.2008.01553.x. [Link]

Urrutia, R. and M. Vuille, 2009: Climate change projections for the tropical Andes using a regional climate model: Temperature and precipitation simulations for the end of the 21 st century. J. Geophys. Res., 114, D02108, doi: 10.1029/2008JD011021. [Link]

Willmott, C. J. and K. Matsuura, 2001: Terrestrial Air Temperature and Precipitation: Monthly and Annual Climatologies (Version 3.02). Global Air Temperature and Precipitation Archive. Available at: http://climate. geog.udel.edu/ climate/html_pages/README. ghen clim2.html. 